\title{
Palladium Catalysts for the Suzuki Cross-Coupling Reaction: An Overview of Recent Advances
}

\author{
Fabio Bellina, Adriano Carpita, Renzo Rossi* \\ Dipartimento di Chimica e Chimica Industriale, Università di Pisa, Via Risorgimento 35, 56126 Pisa, Italy \\ Fax +39(050)2219260; E-mail: rossi@dcci.unipi.it \\ Received 28 May 2004; revised 16 June 2004
}

Dedicated to Professor Akira Suzuki in recognition of his very important contributions to organometallic chemistry and organic synthesis.

\begin{abstract}
This review with 206 references covers the literature published until March 2004 on the development and applications of new efficient catalyst systems for the Suzuki palladium-catalysed cross-coupling reaction of organoboron compounds with organic electrophiles. Where possible, the relative advantages of the new catalyst systems in this synthetically very important carbon-carbon bond forming reaction have been compared.

1 Introduction

2 Palladacycle Complexes as Catalyst Precursors

3 Catalyst Systems Composed of Pd(0) or Pd(II) Derivatives and Electron-Rich and/or Bulky Phosphine Ligands

4 Catalyst Systems Composed of Pd(0) or Pd(II) Derivatives and $\mathrm{N}$-Heterocyclic Carbene Ligands

$5 \quad$ Water-Soluble Catalyst Precursors

$6 \quad$ Ligandless Catalyst Precursors

7 Other Novel Pd Catalyst Precursors

8 Conclusions
\end{abstract}

Key words: palladium, complexes, boron, catalysis, cross-coupling

\section{$1 \quad$ Introduction}

The Suzuki palladium-catalysed cross-coupling reaction of organoboron compounds with organic halides or pseudo-halides is a remarkably useful tool in organic synthesis. During the past decade, this reaction for carboncarbon bond formation, which proceeds under mild conditions, is largely unaffected by the presence of water, tolerates a broad range of functionality and yields nontoxic byproducts. The reaction has largely been employed in academic laboratories as well as in pharmaceutical and fine chemical industries to synthesise a large variety of organic molecules. For example, it has been applied industrially to the production of Losartan (1), ${ }^{1}$ which is a Merck antihypertensive drug, and has been used for the large scale synthesis of compound $\mathbf{2}$, which is a key intermediate for the synthesis of SB-245570 (3), ${ }^{2}$ a compound useful for the treatment of depression, and as a key step in a convergent multikilogram synthesis of CI-1034 (4) (Figure 1), ${ }^{3}$ a potent endothelian receptor antagonist.

The scope of the Suzuki reaction for synthetic applications has been surveyed in several excellent reviews

SYNTHESIS 2004, No. 15, pp 2419-2440

Advanced online publication: 16.09.2004

DOI: 10.1055/s-2004-831223; Art ID: E11404SS

(c) Georg Thieme Verlag Stuttgart · New York
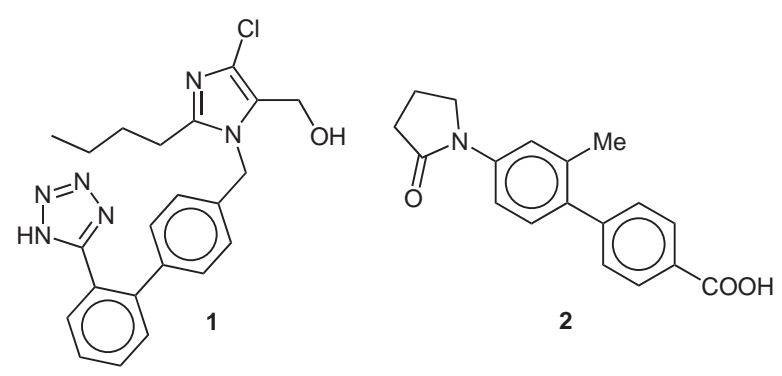

2

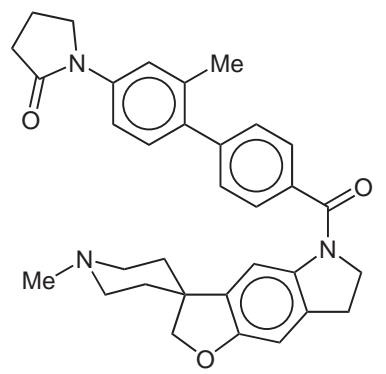

3 which cover the work before $1998^{4-9}$ and the developments from 1999 to 2001 have been surveyed by Kotha, Lahiri and Kashinath ${ }^{10}$ and by Miyaura. ${ }^{11}$

On the other hand, the review published in 2001 by LloydWilliams and Giralt ${ }^{12}$ concerns the use of the Suzuki coupling for the synthesis of peptide biphenyls, and a section of the review published in 2002 by Littke and $\mathrm{Fu}^{13}$ summarises several results from 1986 to late 2001 in the area of the palladium-catalysed Suzuki cross-coupling reactions of aryl chlorides.

The present review aims to complete the picture of the studies carried out so far on the Suzuki palladium-catalysed cross-coupling reactions and, in particular, is intended to give an overview on recent developments in the area of new efficient catalyst systems for this reaction and their activity towards challenging substrates. Significant contributions on these aspects from 1994 to 2001, which have been considered shortly and/or partly in four of the above mentioned reviews, ${ }^{10-13}$ are highlighted in this article, which also covers developments which appeared from 2001 to March 2004.

The topics that are covered in the present discussion include: i) the description of the structures and applications 
of palladacycle complexes as efficient catalyst precursors; ii) the development and use of catalyst systems composed of $\mathrm{Pd}(0)$ or $\mathrm{Pd}(\mathrm{II})$ derivatives and electron-rich and/or bulky phosphine ligands; iii) Suzuki cross-coupling reactions by catalyst systems composed of $\mathrm{Pd}(0)$ or $\mathrm{Pd}(\mathrm{II}) \mathrm{de}$ rivatives and nucleophilic $N$-heterocyclic carbene ligands; iv) Suzuki cross-coupling reactions by water-soluble catalyst precursors; v) Suzuki cross-coupling reactions by ligandless catalyst precursors; and vi) Suzuki cross-coupling reactions by other novel palladium catalyst precursors.

\section{Palladacycle Complexes as Catalyst Precur- sors}

Recently, there has been considerable interest in the development of new, high-activity catalysts that can be used in low loadings in Suzuki cross-coupling reactions. In this regard, palladacycle complexes, where the ligand is in a position to coordinate to the metal center through both a metalated carbon and a donor atom, have shown considerable promise ${ }^{14,15}$ In fact, given their high activity and longevity, palladacycle complexes would appear to be ideal candidates for recycling protocols. Moreover, these complexes that, according to Shaw, ${ }^{16}$ might operate through a $\mathrm{Pd}(\mathrm{II})-\mathrm{Pd}(\mathrm{IV})$ catalytic cycle instead of by the traditional $\operatorname{Pd}(0)-P d(I I)$ mechanism, exhibit higher air and thermal stability than $\operatorname{Pd}(0)$ complexes. The structures of palladacycles 5-25 used so far as catalyst precursors for Suzuki cross-coupling reactions are illustrated in Figure 2.

Pioneering work in this area was reported in 1995 by Herrmann et al., ${ }^{17}$ who found that the thermally stable phosphorus-based palladacycle $\mathbf{5}$ is able to catalyse Suzuki couplings of activated aryl chlorides with catalyst precursor loadings as low as $0.1 \%$. Interestingly, complex $\mathbf{5}$ was also shown to be one of the most efficient palladium catalyst precursors for a Suzuki-like reaction between aryldiazonium tetrafluoroborates and potassium aryltri-

\section{Biographical Sketches}
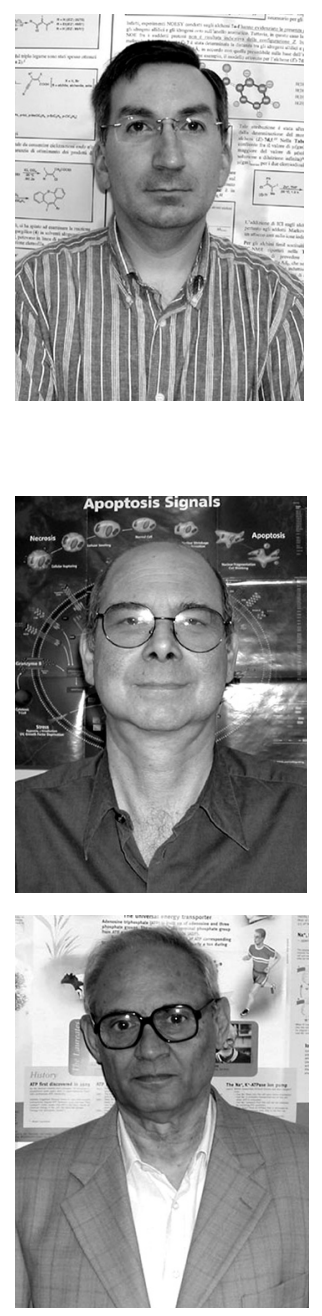

Fabio Bellina was born in Catania (Italy) in 1964. He studied Chemistry at the University of Pisa and received his Laurea Degree in 1990 under the supervision of Professor R. Rossi. In 1992, after his national service, he joined the University of Pisa as an Organic Chemistry Researcher at the

Adriano Carpita was born in San Miniato (Italy) in 1953. He received his Laurea Degree in Chemistry in 1978 at the University of Pisa and the Scuola Normale Superiore of Pisa, under the supervision of

Renzo Rossi was born in Pisa (Italy) in 1937. He graduated in Chemistry at the University of Pisa in 1960, working with Professor P. Pino. In 1969, he became Assistant Professor and, after holding other intermediate positions, in 1980 he became Full Professor of Organic Chemistry at the University of Calabria. In 1982, he joined again the
Dipartimento di Chimica e Chimica Industriale, working under the supervision of Professor R. Rossi. In October 2003 he was appointed by the Faculty of Science of the University of Pisa as an Associate Professor of Organic Chemistry. Most of his research has been devoted to the study of transition

Professor R. Rossi. After postdoctoral work in 1981, he became Researcher at the Scuola Normale Superiore and in 1988 he became Associate Professor of Organic Chemistry at the University of Pisa. His main research

University of Pisa where he has held the Chair of Chemistry of Naturally Occurring Compounds at the Faculty of Sciences. At the beginning of his career he was interested in stereochemistry and the study of insect pheromones and naturally occurring phototoxins. His current research interests include transition metal-catalysed carbon-carbon and metal-catalysed reactions and their application to the selective synthesis of bioactive natural and synthetic heterocyclic compounds, and particularly of substances which are cytotoxic against human tumor cell lines.

interests have focused on the application of transition metal-catalysed reactions in organic synthesis and the synthesis of compounds of biological interest, and particularly of antitumor agents.

carbon-heteroatom bond forming reactions and their synthetic applications in the field of fine chemistry, and particularly in the field of pharmacologically active compounds, the synthesis of anticancer compounds, and the total synthesis of biologically active natural products. 


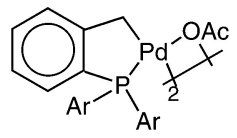

$5: \mathrm{Ar}=2-\mathrm{MeC}_{6} \mathrm{H}_{4}$<smiles></smiles>

8a: $\mathrm{R}^{1}=\mathrm{Ph} ; \mathrm{R}^{2}=\mathrm{H}$

8b : $\mathrm{R}^{1}=4-\mathrm{ClC}_{6} \mathrm{H}_{4} ; \mathrm{R}^{2}=\mathrm{Cl}$

8c: $\mathrm{R}^{1}=4-\mathrm{MeOC}_{6} \mathrm{H}_{4} ; \mathrm{R}^{2}=\mathrm{OMe}$

$8 d: R^{1}=M e ; R^{2}=H$

$8 e: R^{1}=\mathrm{Me} ; \mathrm{R}^{2}=\mathrm{OH}$

$8 f: R^{1}=4-\mathrm{HOC}_{6} \mathrm{H}_{4} ; \mathrm{R}^{2}=\mathrm{OH}$
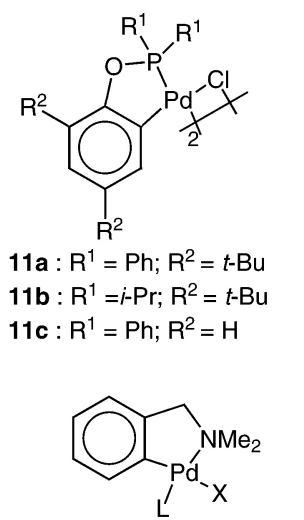

14a: $\mathrm{X}=\mathrm{OCOCF}_{3} ; \mathrm{L}=\mathrm{PCy}_{3}$

14b: $\mathrm{X}=\mathrm{OCOCF}_{3} ; \mathrm{L}=\mathrm{PPh}_{3}$

14c: $X=\mathrm{OCOCF}_{3} ; \mathrm{L}=\mathrm{AsPh}_{3}$

14d: $X=$ OCOCF $_{3} ; L=P\left(4-C_{3} \mathrm{C}_{6} \mathrm{H}_{4}\right)_{3}$

14e: $X=\mathrm{OCOCF}_{3} ; \mathrm{L}=\mathrm{P}\left(4-\mathrm{MeOC}_{6} \mathrm{H}_{4}\right)_{3}$

14f: $\mathrm{X}=\mathrm{Cl} ; \mathrm{L}=\mathrm{PPh}_{3}$

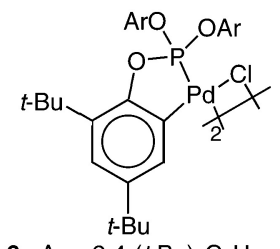

$6: \mathrm{Ar}=2,4-(t-\mathrm{Bu})_{2} \mathrm{C}_{6} \mathrm{H}_{3}$<smiles></smiles>

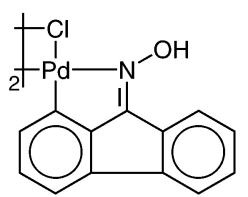

9<smiles>[R]c1cc2c3c(c1)O[Pb](OC(F)(F)F)(O2)[P+]3Pc1ccccc1</smiles>

$10 a: \mathrm{R}=\mathrm{H}$

$10 \mathrm{~b}: \mathrm{R}=\mathrm{Me}$<smiles>[R7]C1[R5]([H])[R]([R])(C([X])(C)C)c2ccccc21</smiles><smiles>[Y]C1(C)N2Cc3ccccc3[P+]21[Y]</smiles>

13a: $\mathrm{X}=\mathrm{Cl}$

13b : $\mathrm{X}=\mathrm{OCOCF}_{3}$

12a : $R^{1}=\mathrm{Me} ; \mathrm{R}^{2}=t-\mathrm{Bu} ; \mathrm{X}=\mathrm{Cl}$

12b : $\mathrm{R}^{1}=\mathrm{Me} ; \mathrm{R}^{2}=t-\mathrm{Bu} ; \mathrm{X}=\mathrm{OAC}$

12c: $\mathrm{R}^{1}=\mathrm{H} ; \mathrm{R}^{2}=t-\mathrm{Bu} ; \mathrm{X}=\mathrm{Cl}$

12d $: R^{1}=R^{2}=M e ; X=C l$

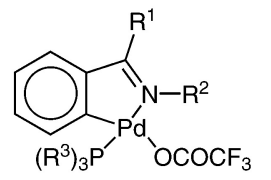

15a: $\mathrm{R}^{1}=\mathrm{Me} ; \mathrm{R}^{2}=i-\mathrm{Pr} ; \mathrm{R}^{3}=\mathrm{Ph}$

15b: $R^{1}=H ; R^{2}=R^{3}=P h$

15c: $\mathrm{R}^{1}=\mathrm{H} ; \mathrm{R}^{2}=i-\mathrm{Pr} ; \mathrm{R}^{3}=\mathrm{Cy}$

15d: $\mathrm{R}^{1}=\mathrm{H} ; \mathrm{R}^{2}=i-\mathrm{Pr} ; \mathrm{R}^{3}=\mathrm{Ph}$

Figure 2a

fluoro-borates, affording the expected biaryls as a result of a cross-coupling. ${ }^{18}$

On the other hand, the dimeric complex 6, which can be prepared by reaction of tris(2,4-di-tert-butylphenyl)phosphite with $\mathrm{PdCl}_{2}$, was found to be an active catalyst precursor in the reaction of phenylboronic acid with aryl bromides, giving turnover numbers of up 1,000,000 and turnover frequencies of nearly $900,000 .{ }^{19}$ More recently, Bedford et al. ${ }^{20}$ reported that complex $\mathbf{6}$ is an excellent catalyst precursor, not only for the Suzuki coupling of aryl bromides with aryl- and alkylboronic acids, but also, when used in conjunction with tricyclohexylphosphine $\left(\mathrm{PCy}_{3}\right)$, for the Suzuki coupling of aryl chlorides. A typi-<smiles>Cc1ccccc1Cl</smiles><smiles>Oc1ccccc1</smiles>

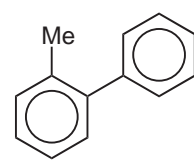

$\mathrm{Cs}_{2} \mathrm{CO}_{3}$ (2 equiv) dioxane, $100{ }^{\circ} \mathrm{C}$ (82\%) cal cross-coupling reaction promoted by $\mathbf{6}$ is shown in Scheme 1.

Weissman and Milstein ${ }^{21}$ introduced the air- and thermally stable phosphine free imine complex 7 as another excellent catalyst for the Suzuki cross-coupling of aryl bromides with phenylboronic acid. They found that this palladacycle leads to turnover numbers of more than $10^{5}$ with nonactivated aryl bromides.

Nájera et al. ${ }^{22-26}$ intensively investigated oxime-derived palladacycles and found that these air- and water-stable complexes are precatalysts suitable for cross-coupling of boronic acids with different aryl and heteroaryl bromides and chlorides, and allyl and benzyl halides. In particular, oxime-derived chloro-bridged palladacycles 8a-d, 9, 20 and 21 were found to be efficient precatalysts for the coupling reaction of phenylboronic acid with 4-bromoacetophenone in toluene at $110{ }^{\circ} \mathrm{C}$ in the presence of $\mathrm{K}_{2} \mathrm{CO}_{3}$ as a base, ${ }^{22,23}$ and palladacycle $\mathbf{2 1}$ was successfully used in the Suzuki reaction of phenylboronic acid with aryl bromides and activated and nonactivated aryl chlorides. ${ }^{23}$

Scheme 1 


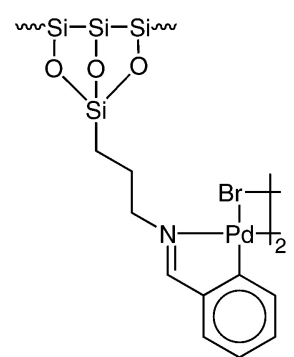

16

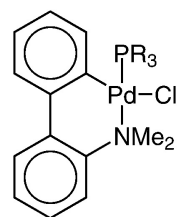

19a $: \mathrm{PR}_{3}=\mathrm{HP}(2$-norbornyl)

$19 \mathrm{~b}: \mathrm{PR}_{3}=\mathrm{HP}(t-\mathrm{Bu})_{2}$

$19 \mathrm{c}: \mathrm{PR}_{3}=\mathrm{HPCy}_{2}$

19d: $\mathrm{PR}_{3}=\mathrm{PCy}_{3}$

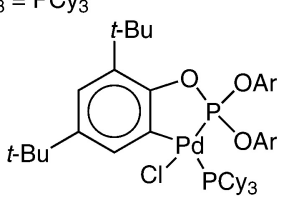

$22: \mathrm{Ar}=2,4-(t-\mathrm{Bu})_{2} \mathrm{C}_{6} \mathrm{H}_{3}$

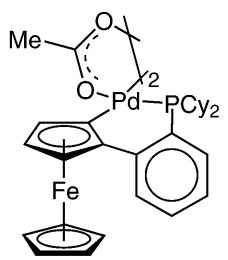

24

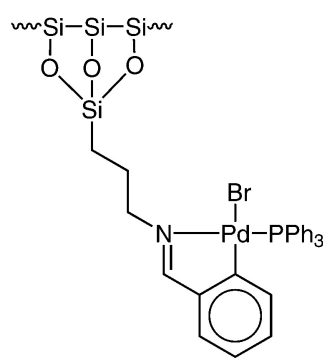

17

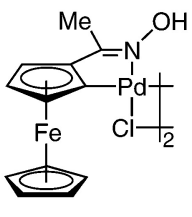

20

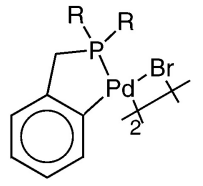

18a $: R=P h$

$18 \mathrm{~b}: \mathrm{R}=t-\mathrm{Bu}$
Turnover numbers of up to 4700 and turnover frequencies up to 4700 per hour were found for reactions involving aryl chlorides. The catalytic activity of palladacycles $\mathbf{8 d -}$ f was tested on a model reaction between phenylboronic acid and 4-chloroacetophenone, which was carried out either in water at $100{ }^{\circ} \mathrm{C}$ in the presence of tetrabutylammonium bromide (TBAB) as additive and $\mathrm{K}_{2} \mathrm{CO}_{3}$ as base (Method A) or in methanol-water (3:1) at room temperature in the presence of TBAB as additive and $\mathrm{KOH}$ as base (Method B). ${ }^{24,25}$ Method A, in which complex $8 \mathbf{e}$ was used as a highly active catalyst at low loading, was more efficient than Method B and was employed for the Suzuki reaction of arylboronic acids with activated and nonactivated aryl chlorides. ${ }^{24,25}$ Interestingly, complex $8 \mathbf{e}$ $(0.05 \mathrm{~mol} \%)$ was also used as precatalyst for the reaction of arylboronic acids with benzyl chlorides and allyl chlorides and acetates, which was performed at room temperature in acetone-water $(3: 2)$ in the presence of $\mathrm{KOH}$ as the base and TBAB as additive. ${ }^{25,26}$ Complex 8e was also used to study the scope of Suzuki reactions involving aryl and heteroaryl bromides, which were performed using a modification of Methods A and B. ${ }^{25}$ This modification, in which TBAB was not used as additive, permitted the preparation of the required biaryls with turnover numbers up to $10^{5}$ and turnover frequencies up to $7 \times 10^{4}$ per hour. $^{25}$ Interestingly, palladacycle $8 \mathbf{e}$ proved also to be able to promote the methylation of 4-bromo- and 4-chloroacylbenzenes with trimethylboroxine (Scheme 2) and the alkylation of aryl chlorides with butylboronic acid in re-

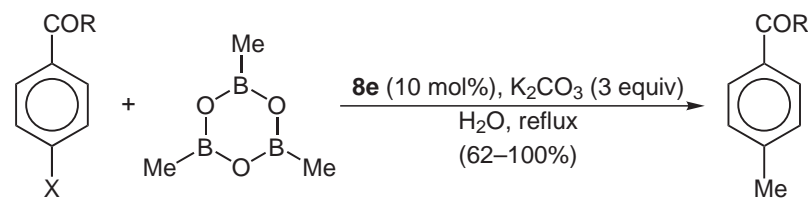

$(\mathrm{R}=\mathrm{Me}, \mathrm{Ph} ; \mathrm{X}=\mathrm{Br}, \mathrm{Cl})$

Scheme 2 
fluxing water in the presence of TBAB as additive and $\mathrm{K}_{2} \mathrm{CO}_{3}$ as a base. ${ }^{25}$

A metalated phosphorus donor system different from that of complex $\mathbf{5}$ is present in the bis(phosphinite) PCP-pincer complexes $\mathbf{1 0 a}$ and $\mathbf{1 0 b}$, which were reported to exhibit excellent activity in the coupling of deactivated and sterically hindered aryl bromides with phenylboronic acid in toluene at $130{ }^{\circ} \mathrm{C}$ in the presence of $\mathrm{K}_{2} \mathrm{CO}_{3} \cdot{ }^{27} \mathrm{On}$ the other hand, the comparatively inexpensive $\mathrm{P}, \mathrm{C}$-bidentate phosphinite palladacycles 11a,b were found to be extremely active catalyst precursors in the coupling of deactivated and sterically hindered aryl bromides. ${ }^{28}$

The sulfur-containing cyclopalladated compounds $\mathbf{1 2 a}-\mathbf{d}$ derived from the ortho-metalation of benzylic tert-butylthioesters were demonstrated to be excellent catalyst precursors for the cross-coupling reaction of 4-bromotoluene with phenylboronic acid. ${ }^{29}$ One of these palladacycles, $\mathbf{1 2 a}$, proved also to be able to promote the crosscoupling of activated and unactivated aryl bromides and chlorides with phenylboronic acid in DMF using $\mathrm{K}_{3} \mathrm{PO}_{4}$ as a base. ${ }^{29}$

In 1998, Bedford et al. demonstrated that the amine-based palladacycle 13a can be used in aryl bromide cross-coupling reactions. ${ }^{30}$ Subsequently, Bedford and Cazin ${ }^{31}$ showed that $14 \mathbf{a}$, the $\mathrm{PCy}_{3}$ adduct of $\mathbf{1 3 b}$, is very active in the Suzuki coupling of aryl chlorides even under aerobic conditions. More recently, these authors explored further the effect of phosphine ligands on the activity of palladated imine and amine catalyst precursors. In particular, they examined the activity of complexes $14 \mathbf{a}-\mathbf{f}$ and $\mathbf{1 5} \mathbf{a}-\mathbf{d}$ in the coupling reaction of 4-bromoanisole with phenylboronic acid ${ }^{32}$ and have found that palladacycles $14 \mathbf{a}-\mathbf{e}, \mathbf{1 5 b}$ and 15d show much greater activity than the parent dimers. Moreover, they observed that while complex 14a performs well in the Suzuki coupling of aryl chlorides, ${ }^{33}$ this palladacycle shows no advantage compared with the far less expensive triphenylphosphine analogue 14b, with aryl bromides as substrates. ${ }^{32}$

Bedford et al. ${ }^{34}$ also investigated the possibility of using silica-supported imine-based palladacycles such as $\mathbf{1 6}$ and 17, but found that these solid-supported catalyst precursors show considerably lower reactivity than their homogeneous counterparts in the Suzuki reaction.

Phosphapalladacyclic complexes 18, which can be synthesised from the corresponding ortho-bromobenzylphosphine ligands, ${ }^{35}$ were demonstrated to be other effective catalyst precursors for the coupling of activated aryl chlorides and bromides with phenylboronic acid. The activity of these complexes was found to be comparable to that of existing palladacycle systems, but did not require a promoting salt. ${ }^{35}$

Highly active catalyst precursors of general formula 19, consisting of a palladacycle and a secondary electron rich and bulky phosphine, were developed by Indolese, Studer et al. ${ }^{36}$ In the Suzuki reaction between phenylboronic acid and unactivated aryl chlorides with palladacycle 19a $(0.01$ mol\%), 660 turnovers were achieved in 20 hours. ${ }^{36}$ This catalytic activity proved to be comparable to screening results by Bedford and Cazin ${ }^{31}$ using a combination of a palladacycle of type 13 with $\mathrm{PCy}_{3}$. Recently, palladacycle 19a has also been used to catalyse the reaction of 4-aryl3-chloro-2(5H)-furanones with arylboronic acids in toluene in the presence of KF as a base. ${ }^{37}$ However, the required 3,4-diaryl-2(5H)-furanones were obtained in low yields.

On the contrary, excellent results have been obtained in Suzuki reactions performed in the presence of catalytic amounts of complex $\mathbf{2 2}$ or $\mathbf{2 3 a} .{ }^{38}$ For example, the reaction of 4-chloroanisole with phenylboronic acid in dioxane at $100{ }^{\circ} \mathrm{C}$ in the presence of $\mathrm{Cs}_{2} \mathrm{CO}_{3}, 0.005 \mathrm{~mol} \% \mathbf{2 3 a}$ and $0.01 \mathrm{~mol}^{2} \mathrm{PCy}_{3}$ (to give 22 in situ) resulted in $100 \%$ conversion and gave a turnover number of $10,000 .{ }^{38}$ Interestingly, palladacycle $\mathbf{2 3} \mathbf{b}$, which is structurally related to 23a, but in which the two non-ortho-metalated aryloxide substituents are replaced by a single salicylate residue, showed in the presence of $\mathrm{PCy}_{3}$ extremely high activity in the Suzuki cross-coupling of deactivated, activated and sterically hindered aryl chlorides. ${ }^{39}$

In 2003, Roca and Richards ${ }^{40}$ reported that air-stable palladacycle $\mathbf{2 4}$ is another very effective precatalyst for the Suzuki cross-coupling of aryl chlorides even at room temperature. In 2004, Sudalai et al. ${ }^{41}$ synthesised a new family of sulfimine-based palladacycles and found that a member of this family, complex 25, exhibits high catalytic activity in the coupling of aryl chlorides with arylboronic acids, affording coupled products in excellent yields.

To conclude this section, it seems advisable to point out, with regard to the involvement of palladacycles in the catalytic cycle of the Suzuki reaction, that accumulating evidence points to such $\mathrm{Pd}(\mathrm{II})$-species requiring an in situ transformation into a $\mathrm{Pd}(0)$-species for entry into the catalytic manifold. ${ }^{42}$

\section{Catalyst Systems Composed of $\operatorname{Pd}(0)$ or Pd(II) Derivatives and Electron-Rich and/or Bulky Phosphine Ligands}

Before 1997, several examples of Suzuki cross-coupling reactions of electron-deficient heteroaryl chlorides with organoboron compounds in the presence of traditional palladium catalyst precursor systems were reported in the literature, ${ }^{13,43}$ but only limited examples concerned aryl chlorides. ${ }^{14,44}$ In 1997, Shen ${ }^{45}$ established that a bulky and electron-rich phosphine, $\mathrm{PCy}_{3}$, is an effective Pd catalyst ligand for the cross-coupling of phenylboronic acid with aryl chlorides bearing electron-withdrawing groups (Scheme 3).

Shen speculated that the electron-richness of $\mathrm{PCy}_{3}$ might make easier oxidative addition of the aryl-chlorine bond to $\operatorname{Pd}(0)$ and that the steric demand of this phosphine 


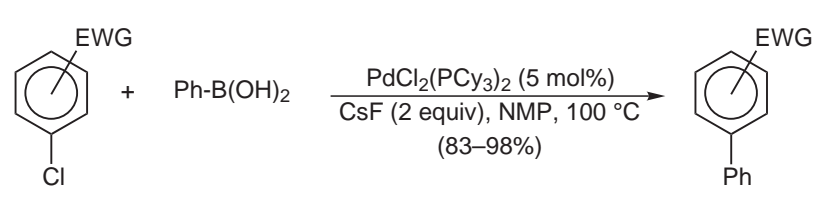

$\left(\mathrm{EWG}=3-\mathrm{MeCO}, 4-\mathrm{CHO}, 3-\mathrm{CHO}, 2-\mathrm{CHO}, 3-\mathrm{NO}_{2}, 3-(E)-\mathrm{CH}=\mathrm{CH}-\mathrm{COOMe}\right)$

Scheme 3

might facilitate ligand dissociation to give a catalytically active monophosphine Pd complex. ${ }^{45}$

Later, catalytic amounts of $\mathrm{PdCl}_{2}\left(\mathrm{PCy}_{3}\right)_{2}$, or of the system composed of $\mathrm{Pd}_{2}(\mathrm{dba})_{3}$ and $\mathrm{PCy}_{3}$, were used for efficient Suzuki reactions of aryl chlorides with boronate esters. ${ }^{46-48}$ Moreover, through the use of the catalyst system consisting of $5 \mathrm{~mol} \% \mathrm{PdCl}_{2}$ and $10 \mathrm{~mol}^{2} \mathrm{PCy}_{3}$ it was possible to synthesise 5-substituted arylfurfurals from 5formyl-2-furylboronic acid and aryl bromides or iodides (Scheme 4). ${ }^{49}$

The observations made by Shen $^{45}$ were confirmed by Monteith, ${ }^{50,51}$ who, during the development of a manifacturing route to 2-cyano-4'-methylbiphenyl, found that electron-rich and bulky phosphines such as $\mathrm{PCy}_{3}, \mathrm{P}(i-\mathrm{Pr})_{3}$ and $\mathrm{P}(i-\mathrm{Bu})_{3}$ are very efficient ligands for Suzuki palladium-catalysed reactions involving activated aryl chlorides.

Another sterically demanding and electron-rich trialkylphosphine, $\mathrm{P}(t-\mathrm{Bu})_{3}$, was used for the first time by Littke and $\mathrm{Fu}^{52}$ in palladium-catalysed cross-couplings between a wide array of electronically and sterically diverse aryl chlorides and arylboronic acids. In these reactions, $\mathrm{Pd}_{2}(\mathrm{dba})_{3}, \mathrm{Cs}_{2} \mathrm{CO}_{3}$ and dioxane were employed as the palladium source, base and solvent, respectively, and a 1.2:1 ratio between $\mathrm{P}$ and $\mathrm{Pd}$ was found to be effective. Later, $\mathrm{Fu}$ et al. ${ }^{53}$ established that $\mathrm{KF}$ is more effective than $\mathrm{Cs}_{2} \mathrm{CO}_{3}$ as a base for Suzuki cross-coupling reactions of activated aryl chlorides with arylboronic acids, and that it allows for reactions to proceed at room temperature in very good yields. Other capabilities of the catalyst system composed of $\mathrm{Pd}_{2}(\mathrm{dba})_{3}$ and $\mathrm{P}(t-\mathrm{Bu})_{3}$ included: $\left.\mathrm{i}\right)$ the synthesis of di- and tri-ortho-substituted biaryls in high yields; ii) the selective coupling of an aryl chloride in preference to an aryl triflate; iii) the use of this catalyst system at low loading; and iv) the high activity of this catalyst system for reactions of arylboronic acids with vinyl chlorides, bromides or iodides. ${ }^{53}$

$\mathrm{Fu}$ et al. ${ }^{53}$ also found that through the use of $\mathrm{Pd}(\mathrm{OAc})_{2} /$ $\mathrm{PCy}_{3}$ as a catalyst precursor, a diverse array of aryl and vinyl triflates react cleanly with arylboronic acids at room temperature.

On the other hand, the catalyst precursor system composed of a 1:4 mixture of $\mathrm{Pd}_{2}(\mathrm{dba})_{3}$ and $\mathrm{PCy}_{3}$ has recently

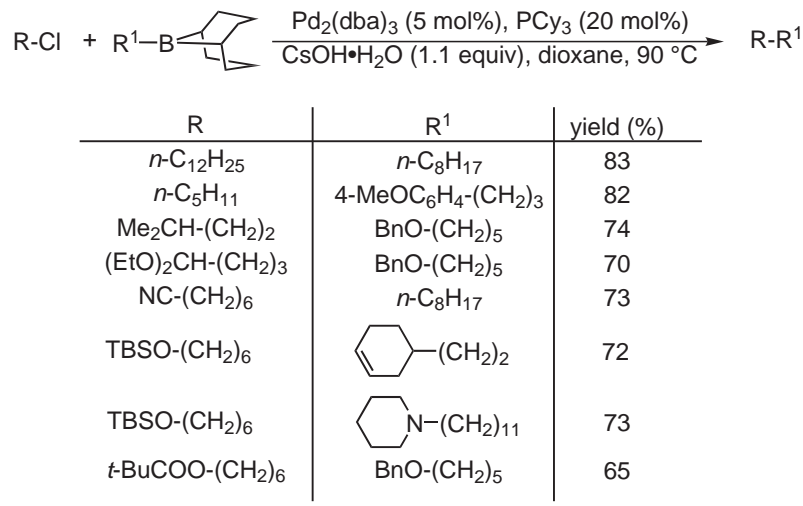

Scheme 5

been found to be effective for cross-couplings of 9-alkyl9-borabicyclo[3.3.1]nonanes with alkyl chlorides in dioxane at $90{ }^{\circ} \mathrm{C}$ in the presence of $\mathrm{CsOH} \cdot \mathrm{H}_{2} \mathrm{O}$ as a base (Scheme 5). ${ }^{54}$

Interestingly, tricyclopentylphosphine $\left[\mathrm{P}\left(c-\mathrm{C}_{5} \mathrm{H}_{11}\right)_{3}\right]$ and $\mathrm{P}(i \text {-Pr })_{3}$, which are phosphines both sterically and electronically similar to $\mathrm{PCy}_{3}$, provided catalyst systems for this reaction significantly less active than that involving $\mathrm{PCy}_{3} \cdot{ }^{54}$ Moreover, for phosphines larger [e.g. $\mathrm{P}(t-\mathrm{Bu})_{3}$ ] or smaller [e.g. $\mathrm{P}(n-\mathrm{Bu})_{3}$ ] than $\mathrm{PCy}_{3}$, essentially no coupling was observed. ${ }^{54}$ Nevertheless, the palladium species generated in situ from $\mathrm{Pd}_{2}(\mathrm{dba})_{3} \cdot \mathrm{CHCl}_{3}$ or $\mathrm{Pd}_{2}(\mathrm{dba})_{3}$ and $\mathrm{P}(t-$ $\mathrm{Bu})_{3}$ has been found to be effective for the coupling of arylboronic acids with bromo- or chloro-substituted 7azaindoles, ${ }^{55}$ with 6 -chloropurines attached to a Rinklinker via their 9-position, ${ }^{56}$ with chlorobiphenyls ${ }^{57}$ and 4 substituted 6-aryl-2-chloropyridines, ${ }^{58}$ for the Suzukitype reaction of an activated aryl chloride with a lithium $n$-alkylborate prepared in situ via addition of sec-butyllithium to a boronate ester (Scheme 6), ${ }^{59}$ and for the regioselective reaction of 4,5-dichloro-1-(dimethyl-aminosulfonyl)imidazole at C-5 with phenylboronic acid in toluene at $90{ }^{\circ} \mathrm{C}$ in the presence of $\mathrm{KF}$ as a base. ${ }^{60}$

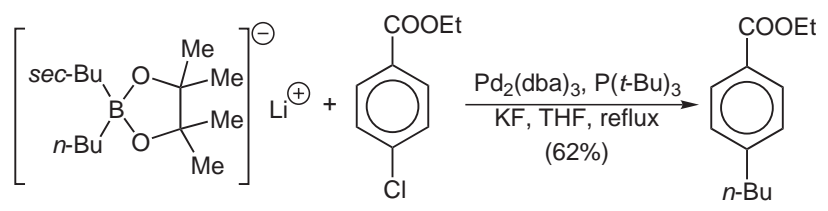

Scheme 6

However, due to its high activity, the precatalyst system composed of $2.5 \mathrm{~mol} \% \mathrm{Pd}_{2}(\mathrm{dba})_{3}$ and $5 \mathrm{~mol} \%$ of an electron rich phosphine such as $\mathrm{P}(t-\mathrm{Bu})_{3}, \mathrm{PCy}_{3}$ or (o-biphenyl) $\mathrm{P}(t-\mathrm{Bu})_{2}$ proved to be unsuitable for the regioselective

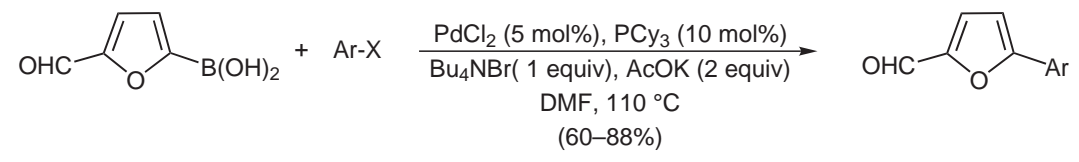

Scheme 4 
monoarylation of 3,4-dichloro-2(5H)-furanone at C-4 by treatment with 1.3 equivalents of an arylboronic acid in toluene at $80{ }^{\circ} \mathrm{C}$ in the presence of $\mathrm{KF}$ as a base..$^{36,61,62} \mathrm{In}$ fact, although under these conditions the conversion of the reaction was high, the desired 4-aryl-3-chloro-2(5H)furanones were obtained along with comparable amounts of the corresponding 3,4-diaryl-2(5H)-furanones (Scheme 7). ${ }^{36,61,62}$<smiles>O=C1OCC(Cl)=C1Cl</smiles>

$$
\begin{gathered}
+\quad \mathrm{Ar}-\mathrm{B}(\mathrm{OH})_{2} \\
\mid \begin{array}{c}
\mathrm{Pd}_{2}(\mathrm{dba})_{3}(2.5 \text { molo }), \mathrm{P}(t-\mathrm{Bu})_{3}(5 \mathrm{~mol} \%) \\
\mathrm{KF}\left(3.3 \text { equiv), toluene, } 80^{\circ} \mathrm{C}\right. \\
(62 \%)
\end{array}
\end{gathered}
$$<smiles>O=C1OCC(Br)=C1Cl</smiles><smiles>O=C1OCC(Br)=C1Br</smiles>

Scheme 7

The selective monoarylation of 3,4-dichloro-2(5H)-furanone at C-4 was, however, achieved using the catalyst system consisting of $2.5 \mathrm{~mol}_{\%} \mathrm{Pd}_{2}(\mathrm{dba})_{3}$ and $10 \mathrm{~mol} \%$ $\mathrm{P}(\text { o-tolyl })_{3} .{ }^{36,61}$

Although the use of electron-rich trialkylphosphines as ligands for palladium-catalysed Suzuki reactions has permitted the participation of challenging electrophiles such as deactivated aryl chlorides, the use of these phosphines, especially for large-scale applications, is limited by the fact that these commercially available ligands cannot be readily handled in air because of the ease with which they undergo oxidation. However, in 2001, one of these ligands, $\mathrm{P}(t-\mathrm{Bu})_{3}$, was converted into the air-stable phosphonium salt $\left[(t-\mathrm{Bu})_{3} \mathrm{PH}\right] \mathrm{BF}_{4} \cdot{ }^{63}$ This salt, which by deprotonation under the Suzuki coupling conditions by a Brönsted base liberates $\mathrm{P}(t \text {-Bu })_{3}$, was used in combination with $\mathrm{Pd}_{2}(\mathrm{dba})_{3}$ to perform efficient cross-coupling reactions of arylboronic acids with activated aryl chlorides, cyclopentyl chloride and deactivated aryl bromides or iodides in THF at $20-50{ }^{\circ} \mathrm{C}$ in the presence of $\mathrm{KF}$ as a base. ${ }^{63}$ Very recently, this salt has also been used in combination with $\mathrm{Na}_{3} \mathrm{PO}_{4}$ in the palladium-catalysed reaction between aryl- or alkenylboronic acids and an unprotected 2,4-disubstituted 5-chloro-1H-imidazole (Scheme 8). ${ }^{64}$

Electron-rich and bulky trialkylphosphine ligands and their salts have also been used profitably in palladium-catalysed Suzuki reactions involving alkyl halides. In fact,

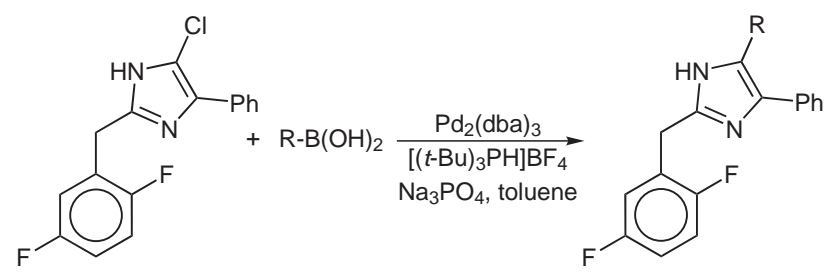

Scheme 8
$\mathrm{Fu}$ et al. ${ }^{65}$ reported that a combination of $\mathrm{Pd}(\mathrm{OAc})_{2}$ and $\mathrm{P}(t-\mathrm{Bu})_{2} \mathrm{CH}_{3}$ or $\left[\mathrm{CH}_{3}(t-\mathrm{Bu})_{2} \mathrm{PH}\right] \mathrm{BF}_{4}$ is able to catalyse efficient room-temperature cross-couplings of alkyl bromides that possess $\beta$-hydrogens with a range of aryl-, vinyl- and alkylboronic acids. These authors also found that alkyl bromides oxidatively add to $\mathrm{Pd}\left[\mathrm{P}(t-\mathrm{Bu})_{2} \mathrm{CH}_{3}\right]_{2}$ at $0{ }^{\circ} \mathrm{C}$ and that the resulting adduct, which was structurally characterised, is able to react with a boronic acid to provide the expected cross-coupled product. ${ }^{65}$

In 2000, Zapf, Ehrentraut and Beller ${ }^{66}$ reported that another excellent precatalyst system for Suzuki reactions of chloroarenes with arylboronic acids is that composed of a mixture of $\mathrm{Pd}(\mathrm{OAc})_{2}$ and the bulky and electron-rich ligand di-(1-adamantyl)-n-butylphosphine. In fact, even with deactivated aryl chlorides, turnover numbers of 10,000-20,000 were achieved for good to excellent yields. On the other hand, the air-stable dimer $\{\operatorname{PdBr}[\mathrm{P}(1-$ adamantyl $\left.\left.)(t-\mathrm{Bu})_{2}\right]\right\}_{2}$ has recently been found to be able to catalyse room-temperature fast cross-coupling reactions between aryl bromides and phenylboronic acid. ${ }^{67}$

Since 1998, the use of supporting 1-di(cyclo)alkylphosphinobiphenyl ligands for the palladium-catalysed Suzuki reaction of aryl chlorides and aryl arenesulfonates has been intensively investigated by the research group of Buchwald. ${ }^{68-74}$ The structures of some of these ligands are reported in Figure 3. In particular, phosphine $\mathbf{2 6}$ proved to be a very effective supporting ligand for the room-temperature palladium-catalysed Suzuki reaction of both electron-rich and electron-deficient aryl chlorides. ${ }^{68}$ Further studies involving ligands 27-29 revealed that catalysts supported by $\mathbf{2 9}$ were more efficient than those supported by 26 and catalysed the room-temperature Suzuki coupling of aryl bromides and chlorides with 0.5-1.0 mol\% Pd. ${ }^{69,70}$ The use of 27 as a ligand was successful for the Suzuki coupling of hindered substrates and allowed these reactions to be carried out at low precatalyst loadings $(0.000001-0.02 \mathrm{~mol} \mathrm{Pd})^{70}$ and catalysts employing ligands 26, 27, 30 and $\mathbf{3 1}$ functioned well for the synthesis of biaryls containing more than one ortho-substituent. ${ }^{70}$ On the other hand, a catalyst system composed of a mixture of ligand $\mathbf{2 6}$ and Pd on carbon was successfully used for the preparation of enantiopure mandelic acids ${ }^{75}$ and a mixture of $\mathrm{Pd}_{2}(\mathrm{dba})_{3}$ and the binaphthyl ligand $(S)-(+)-34$ proved to be effective for the synthesis of axially chiral biaryl compounds in up to $92 \%$ ee..$^{71}$

Buchwald et al. ${ }^{72}$ also reported that a variety of tetraortho-substituted biaryls can be synthesised in 55-98\% yield by Suzuki palladium-catalyzed cross-coupling reactions in which doubly ortho-substitued phosphine 32a was used as a supporting ligand. Recently, Nguyen, Huang and Buchwald ${ }^{73}$ found that a mixture of $2 \mathrm{~mol} \%$ $\mathrm{Pd}(\mathrm{OAc})_{2}$ and $5 \mathrm{~mol} \%$ ligand 33 (XPhos) represents a general precatalyst for the reaction of unactivated aryl tosylates with arylboronic acids.

In 2004, Buchwald et al. ${ }^{74}$ have demonstrated that tuning of steric and electronic properties of dialkylphosphinylbiphenyls affords the new ligand 35, which they used in 


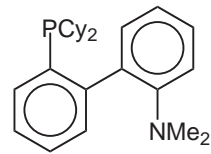

26

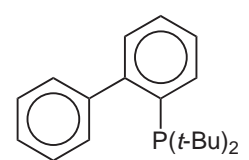

29

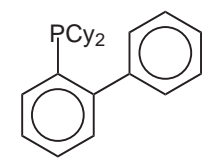

27

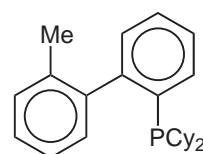

30

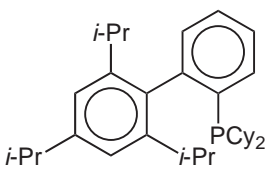

33

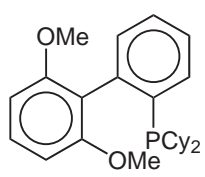

35
Figure 3

combination with $\mathrm{Pd}(\mathrm{OAc})_{2}$ to perform coupling reactions between electron-rich aryl chlorides and the very hindered 2,4,6-triisopropylphenylboronic acid in toluene at 100 $110^{\circ} \mathrm{C}$ in the presence of $\mathrm{K}_{3} \mathrm{PO}_{4} \cdot \mathrm{H}_{2} \mathrm{O}$ as a base.

The catalyst system consisting of ligand $\mathbf{3 5}$ and $\mathrm{Pd}(\mathrm{OAc})_{2}$ in a 2.5:1 molar ratio was also found to be remarkably active for the cross-coupling of unactivated aryl bromides with 2-methyl- and 2-phenylphenylboronic acid. ${ }^{74}$ Moreover, compound $\mathbf{3 5}$ was used as a supporting ligand for the palladium-catalysed synthesis of hindered biaryls, in high-yielding palladium-catalysed couplings of arylboronic acids with a variety of heteroaryl chlorides, in Suzuki couplings at room temperature involving aryl chlorides, and in Suzuki reactions between alkylboron derivatives and aryl halides. ${ }^{74}$

It should also be noted that the use of air-stable and commercially available phosphine $\mathbf{2 7}$ as a supporting ligand permitted successful palladium-catalysed reactions of arylboronic acids with a variety of electrophiles, including halopyridines and haloquinolines, ${ }^{76}$ 6-halonucleosides ${ }^{77}$ and the $O^{6}$-(2-mesitylenesulfonyl) derivatives of $2^{\prime}$-deoxyguanosine (36) (Figure 4), ${ }^{78}$ the derivatization of aryl halides with fluorescent 4-(4,5-diphenyl)- $1 \mathrm{H}$-imidazol-2yl)phenylboronic acid (37) $)^{79}$ and the cross-coupling reaction of 2-chloro-5-nitrobiphenyl (38) (Figure 4) with arylboronic acids. ${ }^{80}$

In 2001, Buchwald et al. ${ }^{81}$ demonstrated that a palladium catalyst based on polymer-supported dicyclohexylphoshinobiphenyl 39 (Figure 4) is active for reactions of arylboronic acids with aryl iodides, bromides and chlorides.<smiles>CCCCOc1nc(N)nc2c1ncn2C1CC(O)C(COCC)O1</smiles>

$36: \mathrm{R}=2,4,6-\mathrm{Me}_{3} \mathrm{C}_{6} \mathrm{H}_{2}$<smiles>O=C(O)c1ccc(-c2nc(-c3ccccc3)c(-c3ccccc3)[nH]2)cc1</smiles>

37

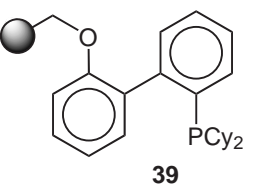

38

39

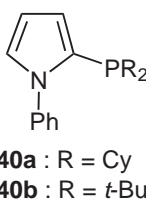

$40 \mathrm{a}: \mathrm{R}=\mathrm{Cy}$
$40 \mathrm{~b}: \mathrm{R}=t-\mathrm{B} u$

\section{Figure 4}

They also reported that filtration of this resin-bound precatalyst from the reaction mixture allows for simplified product isolation via an aqueous workup. Interestingly, the precatalyst could be recycled without additional palladium.

2-Dicyclohexyl- and 2-di-t-butylphosphino-1-phenylpyrrole (40a and 40b, respectively, Figure 4) are other ligands which have been used for highly efficient Suzuki reactions of electron-rich, as well as electron-poor, aryl chlorides with phenylboronic acid at very low precatalyst concentrations. ${ }^{82}$

In recent years, much attention has also been devoted to the synthesis and application of ligands of the family of ferrocenylphosphines in palladium-catalysed Suzuki coupling of aryl halides..$^{83-88}$ The structures of some of these ligands are shown in Figure 5.

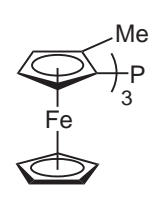

41

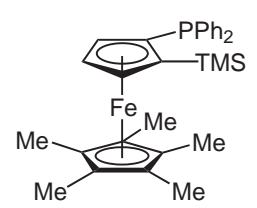

42

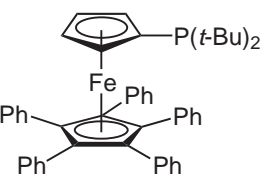

43

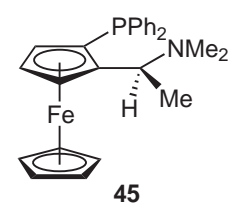

44a $: \mathrm{Ar}=\mathrm{Ph}$
44b $: \mathrm{Ar}=2-\mathrm{MeOC}_{6} \mathrm{H}_{4}$ 44c : Ar =1-naphthyl 44d : Ar = 9-phenanthrenyl

Figure 5

Thus, the $\mathrm{C}_{3}$-symmetric phosphine $(\mathrm{p} S, \mathrm{p} S, \mathrm{p} S)$-tris $(2-$ methylferrocenyl)phosphine (41), ${ }^{83,84}$ the air-stable ferrocene-derived triarylphosphine $\mathbf{4 2},{ }^{85}$ and air-stable electron-rich (pentaphenylferrocenyl)di-tert-butylphosphine $(\mathbf{4 3})^{86}$ are ligands which, in combination with $\mathrm{Pd}(\mathrm{dba})_{2}$, generate active catalysts for Suzuki reactions of aryl chlorides. Moreover, palladium catalysts containing ligand $\mathbf{4 3}$ have also been shown to be effective for the coupling of 
electron-rich and electron-poor aryl bromides with aryland primary alkylboronic acids. ${ }^{86}$

Other air-stable ligands of the ferrocenylphosphine family are the aryl-ferrocenyl derivatives 44 carrying the bis(dicyclohexyl)phosphino moiety. ${ }^{87}$ These ligands were applied in the palladium-catalysed Suzuki cross-coupling of activated as well as unactivated aryl chlorides, and in the asymmetric coupling of an aryl bromide with an arylboronic acid. ${ }^{87}$ However, the highest ee value $(54 \%)$ from this ligand series was significantly lower than those obtained using the catalyst system composed of $\operatorname{Pd}_{2}(\mathrm{dba})_{3}$ and ligand $(S)-(+)-34^{71}$ or $\mathrm{PdCl}_{2}$ and the tertiary amine phosphine ligand 45. ${ }^{88}$ In this last case, chiral binaphthalene derivatives were prepared in up to $85 \%$ ee. ${ }^{88}$

The electron-rich and bulky phenyl backbone-derived $\mathrm{P}, \mathrm{O}$ ligands 46a and 46b (Figure 6) have also been investigated for their utility in palladium-catalysed Suzuki reactions. ${ }^{89,90}$ Thus, it was found that ligand $\mathbf{4 6 a}$, in combination with $\mathrm{Pd}(\mathrm{dba})_{2}$, affords an efficient catalyst for cross-coupling reactions of a wide variety of arylboronic acids with aryl iodides, bromides and chlorides, $, 9,90$ and that this ligand is more efficient than $\mathbf{4 6 b}$ in Suzuki reactions involving aryl chlorides. ${ }^{90}$

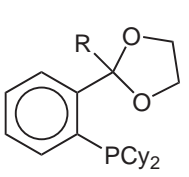

46a $: \mathrm{R}=\mathrm{Me}$ $46 b: R=H$

$$
\left.\mathrm{Ph}-\mathrm{P}_{(}^{\prime} \mathrm{N}_{\mathrm{N}^{\prime}}^{\prime} \mathrm{R}_{\mathrm{R}}^{\mathrm{R}}\right)
$$

50a : $\overparen{R}=\left(\mathrm{CH}_{2}\right)_{5}$

50b : $\overparen{R}=\left(\mathrm{CH}_{2}\right)_{2} \mathrm{O}\left(\mathrm{CH}_{2}\right)_{2}$

\section{Figure 6}

The effectiveness of the $\mathrm{Pd}-\mathbf{4 6 a}$ precatalyst was ascribed to the presence of both the $\mathrm{PCy}_{2}$ and ketal moieties that favour the generation and stability of electron-rich chelating monophosphine $(P, O)$-Pd intermediates. ${ }^{89}$

In 2001, Woollins et al. ${ }^{91}$ prepared the electron-rich amine-functionalised phosphines 47 and 48 (Figure 6) and found that these ligands can also activate palladium complexes to catalyse the Suzuki coupling reaction of aryl chlorides. More recently, a combination of air-stable monoamine phosphine 49 and $\mathrm{Pd}(\mathrm{OAc})_{2}$ has been found to give an efficient catalyst for reaction of aryl bromides with arylboronic acids. ${ }^{92}$ However, the reaction between phenylboronic acid and 4-formylchlorobenzene in the presence of this catalyst system proceeded in a sluggish

manner. When aminophosphine 50a or 50b (Figure 6) was used as the ligand, the reactivity was greatly improved and the desired cross-coupled product was obtained in good yield. ${ }^{92}$

Commercially available bicyclic triaminophosphine $\mathbf{5 1}$ is another ligand that has been used successfully in Suzuki reactions. ${ }^{93}$ In fact, this ligand, in which all three nitrogens linked in the cage to the phosphorus atom are thought to augment the electron-density on phosphorus, was found to be able to activate $\mathrm{Pd}(\mathrm{OAc})_{2}$ to catalyse the cross-coupling reaction of a wide variety of aryl bromides and chlorides with arylboronic acids, affording the desired biaryls in excellent yields. ${ }^{93}$

In 2003, a significant improvement in the scope of the $\mathrm{Su}-$ zuki reaction was realized by Widdowson and Wilhelm, ${ }^{94 a}$ who demonstrated that trimethylphosphine (52), in combination with $\operatorname{Pd}_{2}(\mathrm{dba})_{3}$, provides a catalyst able to promote the cross-coupling reaction of uncomplexed electron-poor aryl fluorides with arylboronic acids. In this way, a ready access to 2,4-dinitrobiphenyls was achieved in good yields from Sanger's reagent. These results were quite interesting since uncomplexed aryl fluorides have long been considered to be inert to palladium(0)-catalysed coupling reactions. ${ }^{95}$ However, Wilhelm and Widdowson ${ }^{94 \mathrm{~b}, 94 \mathrm{c}}$ had previously found that fluoroarenetricarbonylchromium $(0)$ complexes undergo Suzuki reaction with arylboronic acids in DMF at reflux in the presence of $\mathrm{Pd}_{2}(\mathrm{dba})_{3} / \mathbf{5 2} / \mathrm{Cs}_{2} \mathrm{CO}_{3}$ to form biaryltricarbonylchromium $(0)$ complexes.

Nevertheless, at the present time it is known that the use of a catalyst system composed of a palladium derivative and an electron-rich phosphine ligand such as $\mathbf{5 2}$ is not necessary for performing successful palladium-catalysed Suzuki reactions of uncomplexed activated fluoroarenes. In fact, still in 2003 , Kim and $\mathrm{Yu}^{96}$ reported that, when activated by strong electron-withdrawing groups, aryl fluorides are capable of reacting with arylboronic acids in $\mathrm{DMF}$ at $65-80{ }^{\circ} \mathrm{C}$ in the presence of four equivalents of $\mathrm{Cs}_{2} \mathrm{CO}_{3}$ and $10 \mathrm{~mol} \% \mathrm{Pd}\left(\mathrm{PPh}_{3}\right)_{4}$ to give the required biphenyl derivatives in 33-86\% yield.

Recently, it has also been reported that benzyne complex 53 (Figure 7) can be generated by an intramolecular palladium-catalysed Suzuki reaction occurring within an arylpalladium(II) complex containing an ortho-substituted boronic acid. ${ }^{97}$ The required precursor to this complex was prepared by oxidative addition of bromide $\mathbf{5 4}$ to $\mathrm{Pd}(\mathrm{dba})_{2}$ in the presence of $\mathrm{PCy}_{3} \cdot{ }^{97}$

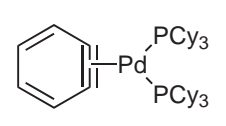

53

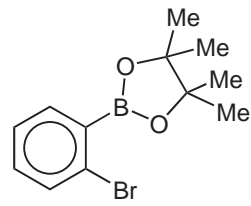

54

Figure 7 
4

The nucleophilic $N$-heterocyclic carbenes (NHC) represent a versatile class of ligands due to their tunable electronic and steric properties. In particular, the imidazol-2ylidenes, which can be considered phosphine mimics, have been regarded as possible alternatives for the widely used phosphine ligands in homogeneous catalysis. ${ }^{98-100}$ In fact, several successful applications of palladium catalyst systems in which these carbenes are used as supporting ligands have been reported in the literature. The success of these ligands is due to the fact that they coordinate tightly to palladium, thus disfavouring the formation of $\mathrm{Pd}$ black, ${ }^{101}$ and that the thermal stability of the Pd-NHC bond avoids the necessity for excess ligand. Moreover, the electron-rich nature of these ligands enhances the rate of oxidative addition and their steric bulk favours the formation of catalytically active monocarbene-palladium species and increases the rate of reductive elimination. ${ }^{102}$

In 1998, Herrmann et al. ${ }^{103}$ began the studies on the activity in Suzuki reactions of palladium catalyst systems containing nucleophilic NHCs as supporting ligands. They found that complex 55 (Figure 8), which is characterised by a bisimidazol-2-ylidene ligand, efficiently promotes the reaction between phenylboronic acid and aryl bromides or activated aryl chlorides in toluene at $120{ }^{\circ} \mathrm{C}$ in the presence of $\mathrm{K}_{2} \mathrm{CO}_{3}$ as the base.

Later, palladium-1,3-bis(2,4,6-trimethylphenyl)imidazol2 -ylidene complexes were reported to be active catalysts for cross-coupling of activated and deactivated aryl chlorides with arylboronic acids, but for effective activation of electron-neutral and electron-rich aryl chlorides, these catalyst systems required temperatures higher than $75{ }^{\circ} \mathrm{C} .{ }^{104}$

It should be noted that, since IMes (56) is considerably less stable to air and moisture than the corresponding imidazolium salt 57a (Figure 8), this carbene has sometimes been generated in situ by deprotonotation of 57a and then used for preparation of the catalytically active palladium complex. ${ }^{102,104}$
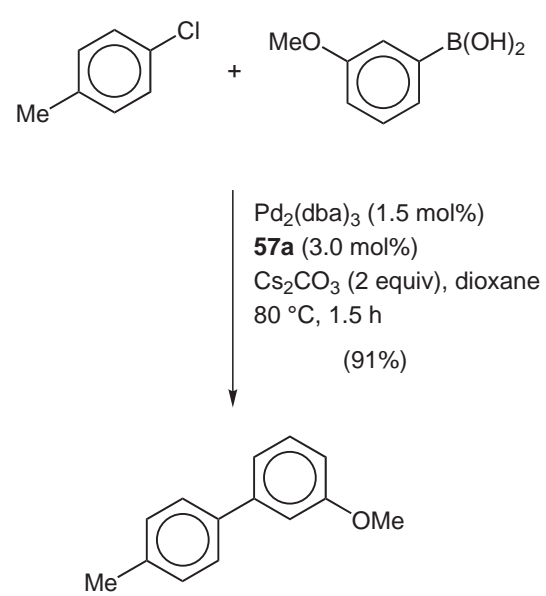

Scheme 9

A typical reaction catalysed by the complex prepared in situ from $\mathrm{Pd}_{2}(\mathrm{dba})_{3}$ and $\mathbf{5 7} \mathbf{a}$ in the presence of $\mathrm{Cs}_{2} \mathrm{CO}_{3}$ is shown in Scheme 9. ${ }^{104}$

The complex prepared in situ from $\operatorname{Pd}_{2}(\mathrm{dba})_{3}$ and the imidazolium salt 57a or 57b has also been used to synthesise a variety of purine derivatives by cross-coupling of chloropurines with boronic acids. ${ }^{105}$

Another efficient catalyst system for high-yielding crosscoupling reactions of aryl chlorides with arylboronic acids is that composed of $\mathrm{Pd}(\mathrm{OAc})_{2}$ and the bisimidazolium salt 58 (Figure 8). ${ }^{106}$ On the other hand, through the use of $\mathrm{Pd}(\mathrm{OAc})_{2}$ and the sterically hindered imidazolium salt $\mathbf{5 9}$ (Figure 8 ) as precatalyst mixture, it was possible to perform efficient cross-coupling reactions of aryl chlorides with 9-alkyl-, 9-allyl-, 9-(1-alkenyl) or 9-cyclopropyl-9borabicyclo[3.3.1]nonane derivatives in the presence of $\mathrm{CH}_{3} \mathrm{OK}$ as the base. ${ }^{107} \mathrm{An}$ example of these reactions is shown in Scheme 10.

Attention has also been directed toward the evaluation of the catalytic activity of homoleptic bis(NHC)-complexes of $\mathrm{Pd}(0)$ such as $\mathbf{6 0}^{108}$ and $\mathbf{6 1}^{109}$ in the Suzuki cross-coupling reaction of aryl chlorides (Figure 9). Herrmann et al. ${ }^{109}$ found that complex $\mathbf{6 1}$ is a highly active precatalyst in the Suzuki cross-coupling reactions of aryl chlorides at room temperature, for which no induction period was ob-

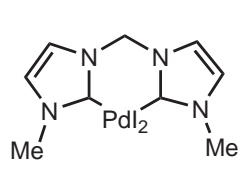

55

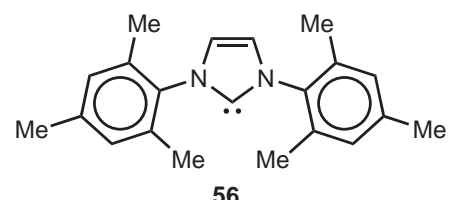

56

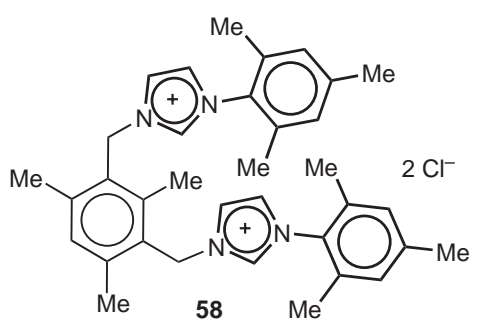

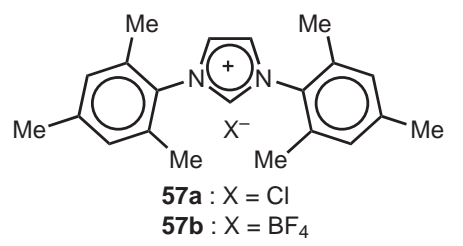

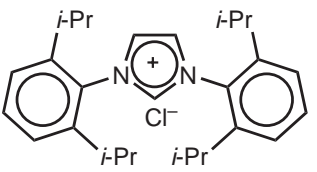

59

Figure 8 
served. However, since it was found that Pd black precipitates during the conversion, the possibility that active clusters of the type $\left[\mathrm{Pd}_{\mathrm{n}}(\mathrm{NHC})_{\mathrm{m}}\right](\mathrm{n}>0.5 \mathrm{~m})$ are formed could not be excluded. ${ }^{109}$

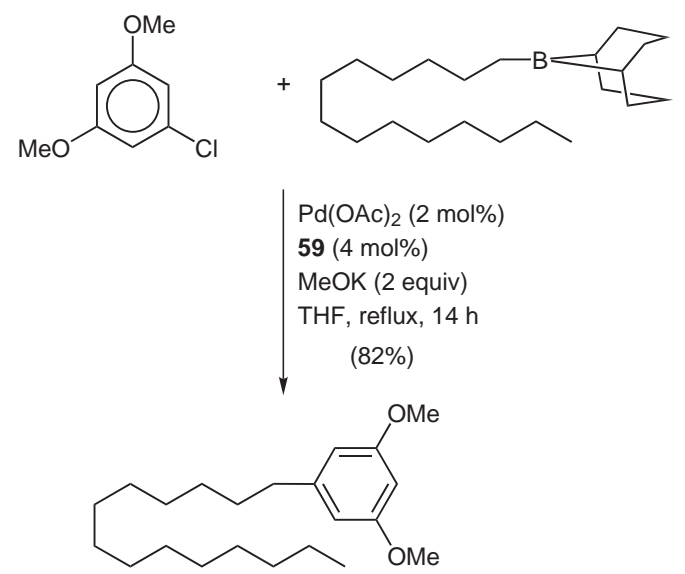

Scheme 10

A variety of mixed Pd(II) complexes of general formula 62 bearing $N$-heterocyclic carbenes and triaryl- or trialkylphosphines have also been prepared (Figure 9). Complexes 62a-d (0.1-1 mol\%) were found to efficiently catalyse the reaction of phenylboronic acid with aryl bromides and chlorides in xylene at $130{ }^{\circ} \mathrm{C}$ in the presence of $\mathrm{K}_{2} \mathrm{CO}_{3}$. ${ }^{110,111}$

In 2003, a notable advance in palladium-catalysed Suzuki reactions was achieved by the development of a general, highly efficient catalyst system for the room-temperature coupling of hindered and unhindered, activated and deactivated aryl chlorides and arylboronic acids. ${ }^{112}$ This catalyst system is composed of $\mathrm{Pd}(\mathrm{OAc})_{2}$ and the $\mathrm{N}$ heterocyclic carbene with flexible steric bulk, which was prepared in situ by treatment of the imidazolium salt $\mathbf{6 3}$ (Figure 9) with KH in THF in the presence of a catalytic amount of $t$-BuOK. For the first time, di- and tri-orthosubstituted biaryls were formed under these conditions and high turnover numbers were obtained. ${ }^{112}$

Recently, some studies have also been performed on the use of polymer-supported $N$-heterocyclic carbenes as ligands for palladium catalysts. ${ }^{113-115}$ In fact, due to their versatile processing capabilities and ease of separation and recycling, polymer-supported precatalysts can offer several advantages for industrial applications. In 2004, Byun and Lee ${ }^{115}$ prepared the novel polymer-supported Pd-NHC complex 64 (Figure 9) and found that this complex is an efficient precatalyst for the cross-coupling of aryl iodides and bromides with phenylboronic acid under aqueous conditions.

Finally, it is worth mentioning that in 2000, Welton et al. ${ }^{116}$ found that $\mathrm{Pd}\left(\mathrm{PPh}_{3}\right)_{4}$-catalysed Suzuki cross-coupling reactions can be conducted in the ambient temperature ionic liquid 1-butyl-3-methylimidazolium tetrafluoroborate (65) (Figure 10), exhibiting unprecedented reactivities in addition to easy product isolation and precata-
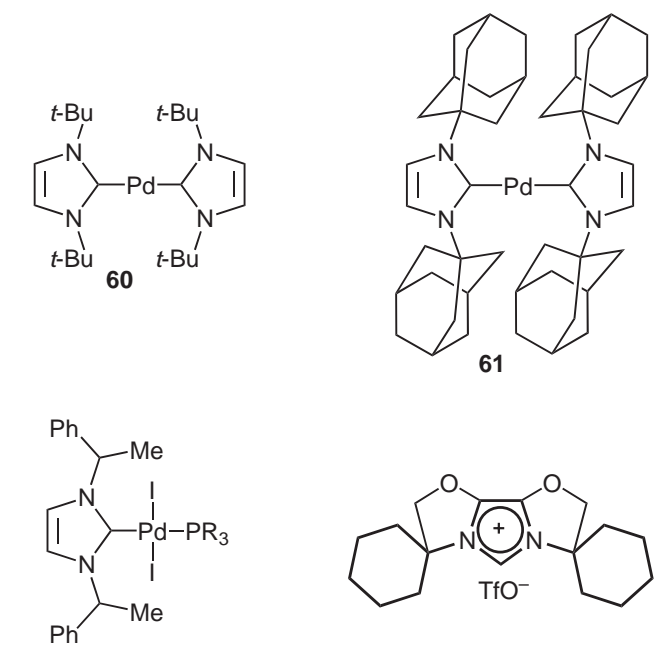

62a $: \mathrm{PR}_{3}=\mathrm{PPh}_{3}$

62b : $\mathrm{PR}_{3}=\mathrm{P}\left(2-\mathrm{MeC}_{6} \mathrm{H}_{4}\right)_{3}$

62c $: \mathrm{PR}_{3}=\mathrm{P}(t-\mathrm{Bu})_{3}$

62d : $\mathrm{PR}_{3}=\mathrm{PCy}_{3}$

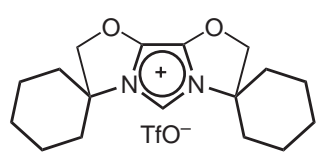

63

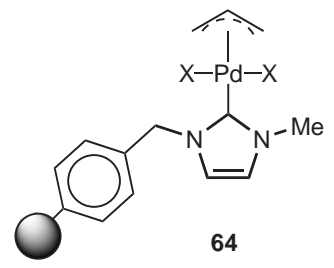

Figure 9

lyst recycling. Later, these authors observed that complexes 66 (Figure 10) can spontaneously form under these conditions. ${ }^{117}$ Moreover, they detected the in situ formation of these complexes in all of the catalytically active solutions derived from reactions of aryl bromides with phenyl- or tolylboronic acid in 65 at $110^{\circ} \mathrm{C}$ in the presence of aqueous $\mathrm{Na}_{2} \mathrm{CO}_{3}$ and catalytic amounts of $\mathrm{Pd}\left(\mathrm{PPh}_{3}\right)_{4}$ or $\mathrm{PdCl}_{2}\left(\mathrm{PPh}_{3}\right)_{2} .118$

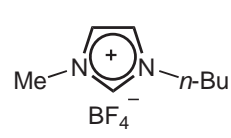

65

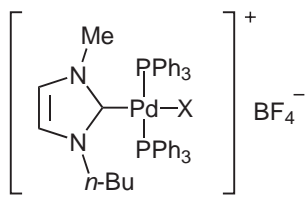

$66: \mathrm{X}=\mathrm{Br}, \mathrm{Cl}$
Figure 10

\section{$5 \quad$ Water-Soluble Pd Catalyst Systems}

During the last two decades, attention has also turned to the development of water-soluble palladium precatalyst systems that can be easily separated from the organic-soluble products at the end of the Suzuki reactions carried out in aqueous media. In 1990, Casalnuovo and Calabrese ${ }^{119}$ found that the water-soluble complex $\mathrm{Pd}\left[\mathrm{PPh}_{2}(m-\right.$ $\left.\left.\mathrm{C}_{6} \mathrm{H}_{4} \mathrm{SO}_{3} \mathrm{M}\right)\right]_{3}\left(67: \mathrm{M}=\mathrm{Na}^{+}, \mathrm{K}^{+}\right.$) efficiently catalyses cross-coupling reactions of aryl iodides and bromides with aryl- and alkenylboronic acids in an aqueous medium. Later, this complex was employed as precatalyst for the synthesis of poly ( $p$-quaterphenylene-2,2'-dicarboxyl- 


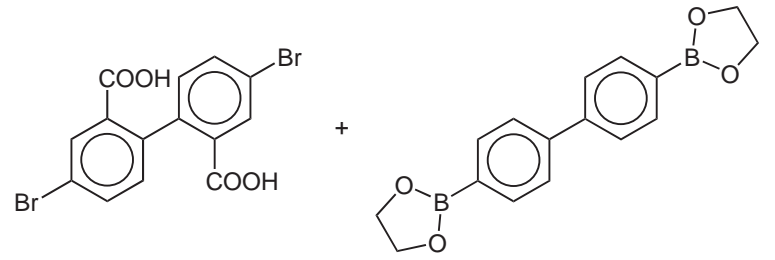

67(1.5 mol\%), $\mathrm{H}_{2} \mathrm{O}$ $30 \% \mathrm{DMF}, \mathrm{NaHCO}_{3}, 85^{\circ} \mathrm{C}$

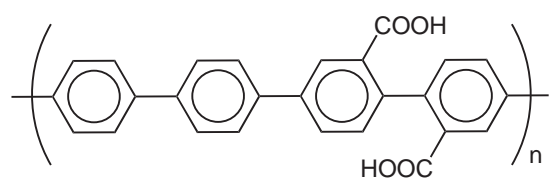

Scheme 11

ic acid) from 4,4'-dibromodiphenic acid and the ethylene glycol diester of 4,4'-biphenylenebis(boronic acid) (Scheme 11). ${ }^{120}$

The structures of other water-soluble palladium precatalysts, and some water-soluble ligands used in combination with palladium compounds to perform Suzuki reactions in aqueous media, are shown in Figure 11.

Thus, a combination of the water-soluble ligand tri(3-sulfonatophenyl)phosphine (TPPTS) $(\mathbf{6 8})$ and $\mathrm{Pd}(\mathrm{OAc})_{2}$ was used by Genêt et al. to generate, in situ, a water-soluble catalyst for the Suzuki reaction of a wide range of arylboronic acids or esters with aryl and alkenyl iodides, ${ }^{121,122}$ and of arylboronic acids with aryl bromides. ${ }^{123}$ For this last process, which provides an efficient access to sterically hindered biaryls, good turnover numbers were observed and the catalyst could be recycled three times without loss of activity.

In 2000, Paetzold and Oehme ${ }^{124}$ reported that water-soluble complex 69 is an excellent catalyst precursor for the two-phase reaction of aryl halides with arylboronic acids in toluene-ethanol-water at $78^{\circ} \mathrm{C}$ in the presence of $\mathrm{Na}_{2} \mathrm{CO}_{3}$ as base and surfactants as phase-transfer agents. It was also observed that with increasing concentration of surfactant, the reaction rates were increased and the formation of byproducts was suppressed.

Compounds 70a and 70b represent another class of ligands designed to solve basic problems of homogeneous catalysis, such as separation and recycling of the catalyst. These hydrophilic carbohydrate-substituted triarylphosphines, in combination with $\mathrm{Pd}(\mathrm{OAc})_{2}$ (ligand: $\mathrm{Pd}=3: 1$ ), gave better results than the catalyst system composed of a $3: 1$ mixture of TPPTS $(\mathbf{6 8})$ and $\mathrm{Pd}(\mathrm{OAc})_{2}$ in cross-coupling reactions of aryl bromides with phenylboronic acid in ethanol-water-di- $n$-butylether $(2: 3: 1)$ or in ethanolwater-toluene at $78{ }^{\circ} \mathrm{C}$ in the presence of $\mathrm{Na}_{2} \mathrm{CO}_{3} .{ }^{125}$

$N$-(4-Diphenylphoshino)phenylmethyl gluconamide (71) is another water-soluble phosphine ligand which was synthesised to perform efficient palladium-catalysed reactions of aryl halides with arylboronic acids in water. ${ }^{126}$
Interestingly, the catalyst precursor prepared from $\mathbf{7 1}$ and $\mathrm{PdCl}_{2}(1,5$-cyclooctadiene) in acetonitrile revealed higher activity than that synthesised from the water-soluble ligands 67 or $68 .{ }^{126}$

Uozumi, Danjo and Hayashi ${ }^{127}$ used the amphiphilic poly(ethyleneglycol)-polystyrene resin-supported palladium-monophosphine complex $\mathbf{7 2}$ to catalyse the reaction of aryl halides and allyl acetates with arylboron compounds in aqueous media. This catalyst could be easily removed from the reaction mixture and reused with no decrease in activity.

Shaughnessy and Booth ${ }^{128}$ prepared two sterically demanding, water-soluble alkylphosphines $\mathbf{7 3}$ and $\mathbf{7 4 ,}$ which were modeled on the steric and electronic properties of $\mathrm{P}(t-\mathrm{Bu})_{3}$, and found that they give highly active palladium catalysts for Suzuki couplings of aryl bromides or chlorides with arylboronic acids in aqueous solvents. These authors also observed that the more sterically demanding ligand $\mathbf{7 4}$ gives catalysts with activity toward aryl chlorides higher than that of the catalysts obtained from 73.

Very recently, Moore and Shaughnessy ${ }^{129}$ have reported that the aqueous-phase Suzuki palladium-catalysed coupling of aryl bromides can also be performed using the sterically demanding sulfonated arylphosphines $\mathbf{7 5 a}$ and $75 b$.

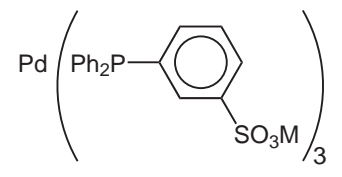

$67: \mathrm{M}=\mathrm{Na}+, \mathrm{K}^{+}$

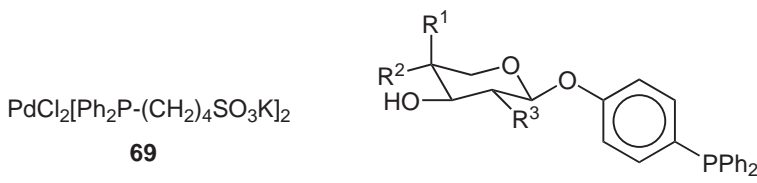

70a : $\mathrm{R}^{1}=\mathrm{H} ; \mathrm{R}^{2}=\mathrm{OH} ; \mathrm{R}^{3}=\mathrm{NHAC}$ 70b : $\mathrm{R}^{1}=\mathrm{OH} ; \mathrm{R}^{2}=\mathrm{H} ; \mathrm{R}^{3}=\mathrm{OH}$
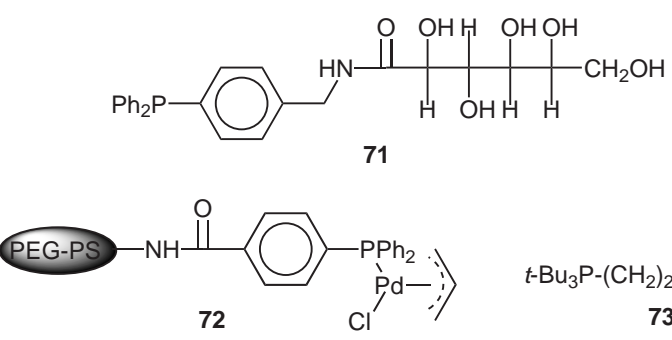

$t-\mathrm{Bu}_{3} \mathrm{P}-\left(\mathrm{CH}_{2}\right)_{2} \mathrm{~N}^{+} \mathrm{Me}_{3} \mathrm{Cl}^{-}$ 73
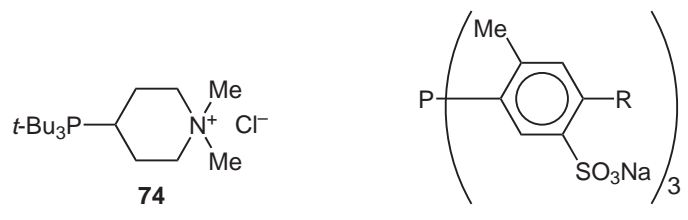

75a $: \mathrm{R}=\mathrm{Me}$ (TXPTS)

$75 b: R=$ OMe (TMAPTS)
Figure 11 


\section{6}

\section{Ligandless Catalyst Precursors}

In 1994, Wallow and Novak ${ }^{130}$ showed that phosphine ligands limit the catalytic efficiency of palladium catalysts in Suzuki reactions of 2-aryl-1,3,2-dioxaborolanes or phenylboronic acid with aryl bromides or iodides. At present, problems due to the use of phosphine-based catalyst systems, namely the two side reactions, aryl-aryl exchange ${ }^{131,132}$ and phosphonium salt formation, ${ }^{133}$ can be suppressed by employing the ligandless methodology. ${ }^{134}$ In fact, the use of ligandless palladium species as catalysts gives rise to a marked improvement in reaction efficiency, allowing for milder reaction conditions and short reaction times, and suppresses the phosphine-related side reactions. ${ }^{131-137}$ Scheme 12 illustrates the preparation of a biphenyl derivative in high yield by an accelerated Suzuki reaction performed in the presence of a catalytic amount of $\mathrm{Pd}(\mathrm{OAc})_{2}$ under ligandless conditions. ${ }^{138}$

Other examples of $\mathrm{Pd}(\mathrm{OAc})_{2}$-catalysed Suzuki reactions have been reported in the literature. Thus, the ligandless $\mathrm{Pd}(\mathrm{OAc})_{2}$-catalysed reaction of aryl bromides with aryland 1-alkenylboronic acids in water without cosolvent, in the presence of a stoichiometric amount of TBAB and a molar excess of $\mathrm{K}_{2} \mathrm{CO}_{3}$, was found to provide the required cross-coupled products in high yields. ${ }^{139}$ Interestingly, under these reaction conditions, aryl iodides gave incomplete conversion, ${ }^{139}$ but 5 -arylfurfurals and arylthiophene2-carboxyaldehydes were efficiently prepared starting from arylboronic acids and 5-bromofurfurals or bromothiophene-2-carboxyaldehydes, respectively. ${ }^{140}$

Moreover, ligand-free $\mathrm{Pd}(\mathrm{OAc})_{2}$ was found to be able to catalyse the coupling reaction of aryl iodides and deactivated aryl bromides with arylboronic acids at room temperature in an aqueous medium ${ }^{141,142}$ and could also be effectively used for preparation of [2] rotaxane $\mathbf{7 6}$ from 4,4'-biphenyldiboronic ester $\mathbf{7 7}$ and diammonium 1-iodonaphthalene-3,6-disulfonate (78) in the presence of $\beta$ -

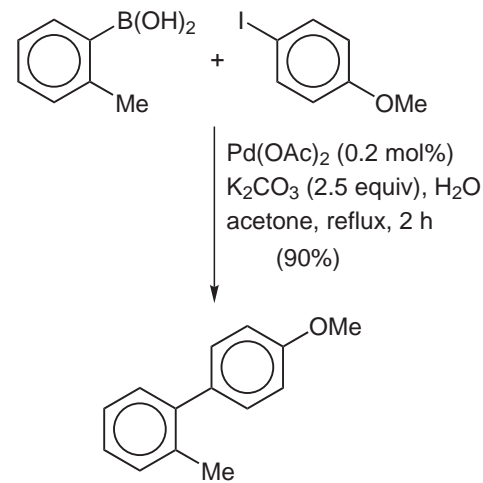

Scheme 12

cyclodextrin ${ }^{143}$ as well as of $(R)$-2-(4-methoxyphenyl)ferrocenecarboxyaldehyde (79) from $(S)$-2-iodoferrocenecarboxyaldehyde (80) and 4-methoxyphenylboronic acid (81) (Figure 12). ${ }^{144,145}$

Molander and Biolatto ${ }^{146}$ recently showed that $\mathrm{Pd}(\mathrm{OAc})_{2}$ can also efficiently catalyse the reaction of potassium aryl- and heteroarylfluoroborates with aryl- or heteroaryl bromides or triflates in refluxing methanol in the presence of $\mathrm{K}_{2} \mathrm{CO}_{3}$ (Scheme 13).

$$
\begin{gathered}
{\left[\mathrm{R}^{1} \mathrm{BF}_{3}\right]^{-} \mathrm{K}^{+}+\mathrm{R}^{2}-\mathrm{X} \frac{\mathrm{Pd}(\mathrm{OAc})_{2}(0.5 \mathrm{~mol} \%)}{\mathrm{K}_{2} \mathrm{CO}_{3}\left(\begin{array}{c}
\text { equiv), } \mathrm{MeOH} \text {, reflux } \\
(50-99 \%)
\end{array}\right.} \mathrm{R}^{1}-\mathrm{R}^{2}} \\
\left(\mathrm{R}^{1}=\text { aryl, heteroaryl; } \mathrm{R}^{2}=\text { aryl, heteroaryl; } \mathrm{X}=\mathrm{Br}, \mathrm{OTf}\right)
\end{gathered}
$$

\section{Scheme 13}

Previously, it had been reported that, in the absence of both base and phosphine ligand, $\mathrm{Pd}(\mathrm{OAc})_{2}$ is able to promote the efficient synthesis of unsymmetrical biaryls by reaction of arenediazonium tetrafluoroborates with arylboronic acids..$^{147,148}$
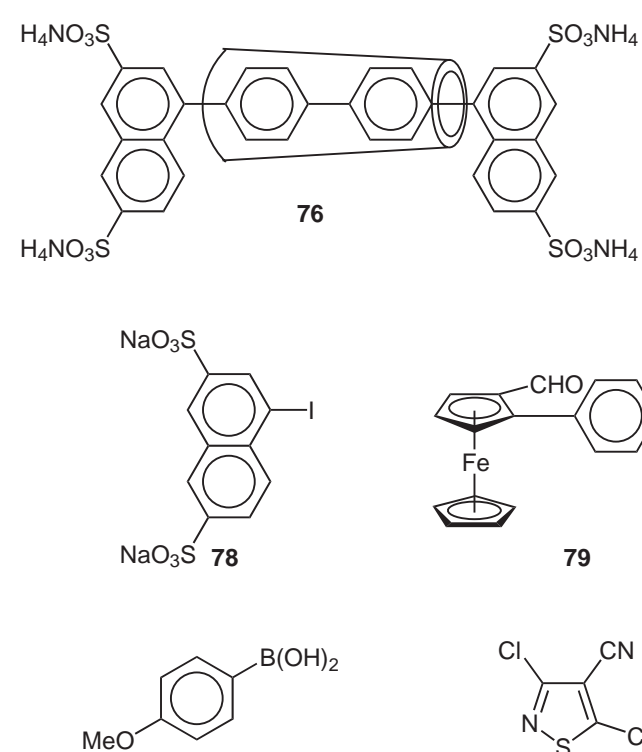

81
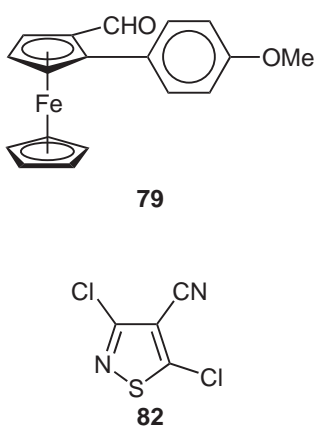

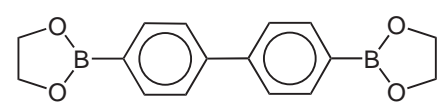

77
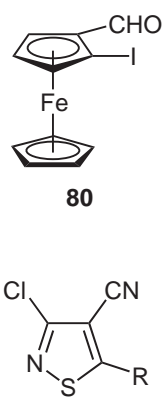

$83: \mathrm{R}=\mathrm{Ar}, \mathrm{Me}$

Figure 12 
Very recently, $\mathrm{Pd}(\mathrm{OAc})_{2}$ has also been shown to be an effective precatalyst for the regiospecific cross-coupling reaction of 3,5-dichloroisothiazole-4-carbonitrile (82) with aryl- and methylboronic acids in refluxing toluene in the presence of KF and 18-crown-6, to give in high yields the 5-substituted 3-chloroisothiazole-4-carbonitriles $\mathbf{8 3}$ (Figure 12). ${ }^{149}$

In 2003, Bedford et al. ${ }^{150}$ determined that $\mathrm{Pd}(\mathrm{OAc})_{2}$ in a mixture of TBAB and water is an effective precatalyst precursor for the cross-coupling of deactivated aryl chlorides with phenylboronic acid. Hess and Kirsch ${ }^{151}$ had previously reported that a catalytic amount of $\mathrm{Pd}(\mathrm{OAc})_{2}$ promotes the reaction of $\beta$-chloroacroleins with arylboronic acids under mild conditions in aqueous media, in the presence of one equivalent of TBAB and 2.5 equivalents of $\mathrm{K}_{2} \mathrm{CO}_{3}$.

With regard to the nature of the catalytically active species formed in the ligandless $\mathrm{Pd}(\mathrm{OAc})_{2}$-catalysed crosscoupling reactions involving arylboronic acids, it must be taken into account that some years ago, the research groups of Moreno-Mañas ${ }^{152}$ and Marcuccio ${ }^{153}$ had independently established that $\mathrm{Pd}(\mathrm{OAc})_{2}$ is reduced to $\mathrm{Pd}(0)$ by arylboronic acids, which undergo self-coupling to give symmetrical biaryls.

In 2003, Deng et al. ${ }^{154}$ described ligand-free $\mathrm{Pd}(\mathrm{OAc})_{2}$ - or $\mathrm{PdCl}_{2}$-catalysed coupling of aryl and alkenyl bromides with arylboronic acids under mild conditions and, very recently, Shen et al. ${ }^{155}$ determined that ligandless $\mathrm{PdCl}_{2}$ catalyses the Suzuki cross-coupling reaction of a series of aryl bromides with arylboronic acids in pyridine, with $\mathrm{K}_{2} \mathrm{CO}_{3}$ as the base, to afford biaryl derivatives in surprisingly high yields.

Bumagin and Korolev ${ }^{156}$ found that ligand-free $\mathrm{Pd}(\mathrm{OAc})_{2}$ is also able to catalyse the cross-coupling reaction of sodium tetraarylborates with acyl chlorides in aqueous or non-aqueous media in the presence of $\mathrm{Na}_{2} \mathrm{CO}_{3}$ as the base to give high yields of unsymmetric ketones. These authors also synthesized phenyl aryl ketones in high yields by reaction of arylboronic acids with benzoyl chloride in aqueous acetone at $20{ }^{\circ} \mathrm{C}$ in the presence of $10 \mathrm{~mol} \% \mathrm{PdCl}_{2}$ and 1.6 equivalents of $\mathrm{Na}_{2} \mathrm{CO}_{3} .{ }^{156}$ Moreover, they observed that the reaction time for the preparation of phenyl $m$-tolyl ketone according to this last procedure was shorter than that of the synthesis of this ketone performed in the presence of $1 \mathrm{~mol} \% \mathrm{PdCl}_{2}\left(\mathrm{PPh}_{3}\right)_{2}$, and that the yield was higher. ${ }^{156}$

Palladium on carbon has been found to be another effective precatalyst for Suzuki reactions. Thus, tetraester $\mathbf{8 6}$ was synthesised in $79 \%$ yield by reaction of iodide $\mathbf{8 4}$ with benzene diboronate ester $\mathbf{8 5}$ in $\mathrm{EtOH}$ in the presence of $\mathrm{Cs}_{2} \mathrm{CO}_{3}$ as the base and $10 \mathrm{~mol} \% \mathrm{Pd}$ on carbon (Figure 13). ${ }^{157}$

Moreover, 5-aryl-2-furaldehydes $\mathbf{8 8}$ were synthesised in $78-91 \%$ yield via coupling of electron-deficient aryl iodides with in situ generated boronic acid 87 (Figure 13) in $\mathrm{EtOH}$ at $60^{\circ} \mathrm{C}$, in the presence of $\mathrm{Et}_{3} \mathrm{~N}$ and a catalytic<smiles>CCOC(=O)c1cccc(I)c1C(=O)OCC</smiles><smiles>CCOC(=O)c1cccc(-c2ccc(-c3cccc(C(=O)OCC)c3C(=O)OCC)cc2)c1C(=O)OCC</smiles>

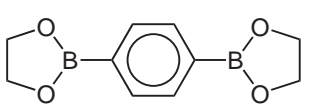

85<smiles>CCOC(OCC)c1ccc(Br)o1</smiles><smiles>O=Cc1ccc(Br)o1</smiles>

88
Figure 13

amount of $10 \% \mathrm{Pd}$ on carbon, followed by acidic aqueous workup. ${ }^{158}$

In 2002, Leadbeater and Marco ${ }^{159}$ used microwave heating to facilitate palladium-catalysed Suzuki reactions under ligandless conditions. Thus, several biaryl derivatives were synthesized in 50-90\% yield by reaction of arylboronic acids with activated aryl iodides, bromides and chlorides in a mixture of $\mathrm{TBAB}$ and water, in the presence of $0.4 \mathrm{~mol} \% \mathrm{Pd}(\mathrm{OAc})_{2}$ and three equivalents of $\mathrm{Na}_{2} \mathrm{CO}_{3}$ using microwave heating. In 2003, Leadbeater and Marco found that the Suzuki coupling of phenylboronic acid with activated and unactivated aryl bromides is possible without the need for a transition metal catalyst, by using one equivalent of $\mathrm{TB} \mathrm{AB}$ as additive and performing the reaction in water under microwave irradiation (a microwave power of $100 \mathrm{~W}$ is optimum). ${ }^{160}$

In 1999 , Schotten et al. ${ }^{161}$ reported that $\mathrm{Pd}(\mathrm{OAc})_{2}$, without an additional phase-transfer compound, is able to promote the reaction of poly(ethyleneglycol)-bound aryl iodides, bromides and triflates with aryl boronic acids in water under conventional thermal conditions $\left(70{ }^{\circ} \mathrm{C}\right.$, two hours) or under microwave irradiation ( $75 \mathrm{~W}$, two to four minutes). Later, these authors used a similar strategy to synthesise compounds of general formula 89 and 90 (Figure 14). ${ }^{162}$

Microwave irradiation was also used by Villemin et al. ${ }^{163}$ to facilitate the ligandless $\mathrm{Pd}(\mathrm{OAc})_{2}$-catalysed reaction of
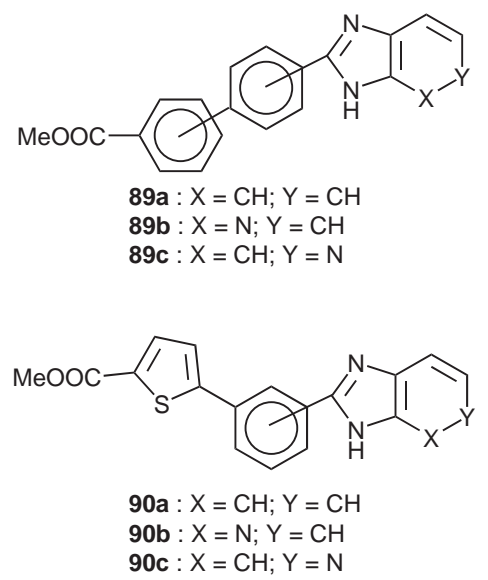

Figure 14 
heteroaromatic halides with commercially available sodium tetraphenylborate in water or monomethylformamide in the presence of $\mathrm{Na}_{2} \mathrm{CO}_{3}$ as the base.

The sulfur-containing palladium complex $\mathrm{PdCl}_{2}(\mathrm{SEt})_{2}$ is another ligandless system which was shown to be an efficient catalyst precursor for the cross-coupling of aryl bromides and chlorides with arylboronic acids. ${ }^{164}$ Interestingly, TBAB, which had a beneficial effect for the reactions catalysed by $\mathrm{Pd}(\mathrm{OAc})_{2}$, had no significant effect when $\mathrm{PdCl}_{2}(\mathrm{SEt})_{2}$ was used as the catalyst. ${ }^{164}$

Palladium powder has also been used as a catalyst precursor for Suzuki reactions. Kabalka et al. ${ }^{165}$ found that aryl iodides readily couple with arylboronic acids in refluxing methanol in the open air, in the presence of a catalytic amount of Pd powder and ca. 14 equivalents of KF. Kabalka and his research group also utilized $\mathrm{Pd}$ powder and a commercially available $\mathrm{KF}-\mathrm{Al}_{2} \mathrm{O}_{3}$ mixture for solventless cross-coupling reactions of aryl and allyl halides and aryl- or alkenylboronic acids. ${ }^{166,167}$ Under these experimental conditions, aryl iodides were found to react faster than the bromides or chlorides. ${ }^{167}$ Moreover, it was observed that the use of microwave irradiation accelerates the reactions by decreasing the reaction times from hours to minutes, ${ }^{167,168}$ and that the palladium catalyst can be recycled using a simple filtration and washing sequence without loss of catalytic activity. ${ }^{167}$

Some other interesting results about Suzuki cross-coupling reactions catalysed by $\mathrm{Pd}$ on carbon have been described. ${ }^{135,169-171}$ For instance, this heterogeneous catalyst proved to be able to catalyse the Suzuki reaction with aryl chlorides at $80{ }^{\circ} \mathrm{C}$ in a 20:1 mixture of dimethylacetamide and water, in the presence of $\mathrm{K}_{2} \mathrm{CO}_{3}$ as the base. ${ }^{170}$ The ability of heterogeneous $\mathrm{Pd}$ to activate the $\mathrm{C}-\mathrm{Cl}$ bond was explained in terms of a synergistic anchimeric and electronic effect that occurs between the Pd surface and the aryl chloride. ${ }^{170}$ On the other hand, a specially optimised air-stable Pd on activated carbon catalyst (i.e. E $105 \mathrm{CA} /$ W 5\% Pd, product of Degussa AG) was demonstrated to be a highly active (TON up to 36,000 ), selective and heterogeneous catalyst for cross-couplings of phenylboronic acid with aryl bromides or activated aryl chlorides. ${ }^{171}$ This catalyst allowed very low palladium concentrations $(0.005 \mathrm{~mol} \%)$ and high conversions of aryl bromides within a few hours. ${ }^{171}$

In recent years, palladium nanoparticles have also been used as catalysts for Suzuki reactions. ${ }^{172-174}$ In fact, these particles have a characteristicly high surface-to-volume ratio and, consequently, a large fraction of the palladium atoms are at the surface and available for catalysis. Thus, palladium nanoparticles stabilised by poly $(N$-vinyl-2-pyrrolidone) were found to be an efficient catalyst for Suzuki reactions in $40 \% \mathrm{EtOH}^{172}$ and a poly $(N, N$-dialkylcarbodiimide)-Pd nanoparticle composite has been demonstrated to be a robust catalyst for Suzuki reactions under microwave or regular heating. ${ }^{174}$ Some evidence was also obtained concerning the presence of nanosized Pd colloids in Suzuki reactions catalysed by $\mathrm{Pd}(\mathrm{OAc})_{2} \cdot{ }^{175}$

Good catalytic activity for cross-coupling reactions of phenylboronic acid with (hetero)aryl iodides and bromides was also shown by hollow palladium spheres synthesised using silica spheres as templates. ${ }^{173}$ Interestingly, these hollow palladium spheres could be reused many times without loss of catalytic activity.

Suzuki cross-coupling reactions of aryl halides, including chlorides, with arylboronic acids were also achieved in the phosphonium salt ionic liquid tetradecylphosphonium chloride in the presence of $\mathrm{K}_{3} \mathrm{PO}_{4}$ and a catalytic amount of $\mathrm{Pd}_{2}(\mathrm{dba})_{3},{ }^{176}$ as well as in the ionic liquid 1,3-di- $n$-butylimidazolium tetrafluoroborate $[\mathrm{bbim}]\left[\mathrm{BF}_{4}\right]$ with methanol as co-solvent under ultrasonic irradiation in the presence of sodium acetate (for bromo- and iodobenzenes) or sodium methoxide (for chlorobenzenes) and a catalytic amount of $\mathrm{Pd}(\mathrm{OAc})_{2} .{ }^{177}$

The heterogeneous catalyst system $\mathrm{PdCl}_{2}$ /tetraphenylphosphonium bromide-intercalated clay was used in 1999 by Varma and Naicker ${ }^{178}$ for the preparation of biaryl compounds in high yields from aryl bromides or iodides and arylboronic acids. It is worth mentioning that this catalyst could be recycled twice without any loss in activity.

In 2003, Paul and Clark ${ }^{179}$ used a novel silica-supported palladium catalyst for the Suzuki reaction between aryl bromides and phenylboronic acid. The key features of the catalyst included rapid reactions, excellent catalyst recyclability and total stability under the reaction conditions.

\section{Other Novel Palladium Catalyst Precursors}

In the last four years, in addition to catalyst systems belonging to the classes described in the preceding sections of this review, several other types of palladium catalysts have been developed and used in Suzuki reactions. In 2001, the catalyst system composed of $5 \mathrm{~mol} \%$ $\mathrm{PdCl}_{2}\left(\mathrm{CH}_{3} \mathrm{CN}\right)_{2}$ and $20 \mathrm{~mol} \% \mathrm{AsPh}_{3}$, which had been previously used for the coupling reaction of cyclopropylboronic acids with $\beta$-tetronic acid triflate $\mathbf{9 1},{ }^{180}$ was employed in an unprecedented, general and efficient procedure for the regioselective synthesis of 4-alkyl-3-bromo-2(5H)-furanones $\mathbf{9 3}$ from alkylboronic acids and easily available 3,4-dibromo-2(5H)-furanone (92) (Figure 15). ${ }^{181}$ To circumvent the sensitivity of dibromide 92 to both water and strong bases, the cross-coupling reactions were performed in THF in the presence of the weak base $\mathrm{Ag}_{2} \mathrm{O}$.

The catalyst system $\mathrm{PdCl}_{2}\left(\mathrm{CH}_{3} \mathrm{CN}\right)_{2} / \mathrm{AsPh}_{3}$ proved also to be effective for the highly regioselective monoarylation of 92 at C-4 and was found to be much more reactive than

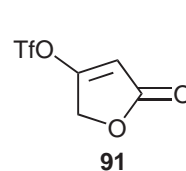

Figure 15
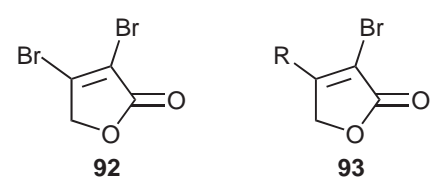
$\mathrm{Pd}\left(\mathrm{PPh}_{3}\right)_{4}$ and the system consisting of $5 \mathrm{~mol} \% \mathrm{Pd}(\mathrm{OAc})_{2}$ and $10 \mathrm{~mol}_{\%} \mathrm{PPh}_{3} .{ }^{182}$

The structures of some other novel palladium catalyst precursors for Suzuki couplings and of some unusual ligands used in these palladium-catalysed reactions are represented in Figure 16.

In 2000 , Griffiths and Leadbeater ${ }^{183}$ reported the use of a combination of $\mathrm{Pd}_{2}(\mathrm{dba})_{3}$ and trimethylphosphite (94) as an efficient precatalyst for the synthesis of sterically hindered biaryls from aryl bromides bearing two ortho substituents and phenylboronic acid. On the other hand, Zapf and Beller ${ }^{184}$ employed tris(2,4-di-tert-butylphenyl)phosphite (95) and tri(isopropyl)phosphite (96) as ligands for the efficient palladium-catalysed coupling reaction of aryl bromides and chlorides with phenylboronic acid. Using these phosphites as ligands, catalyst turnover numbers up to 820,000 were obtained even with deactivated aryl bromides and, for the first time, it was shown that the $\mathrm{Pd}-$ phosphite complex generated in situ also catalyses efficiently the Suzuki reaction of aryl chlorides. ${ }^{184}$

Beller et al. ${ }^{185}$ also demonstrated that the 1,6-diene $\operatorname{Pd}(0)$ monophosphine complexes 97-100 (Figure 16) are extremely efficient catalyst precursors for Suzuki reactions of various aryl chlorides and found that, by variations of both the diene and the phosphine part of the complex, the catalytic properties of these complexes could be tuned. Interestingly, these monophosphine complexes were found to be superior to generally applied mixtures of palladium precatalysts and phosphines.

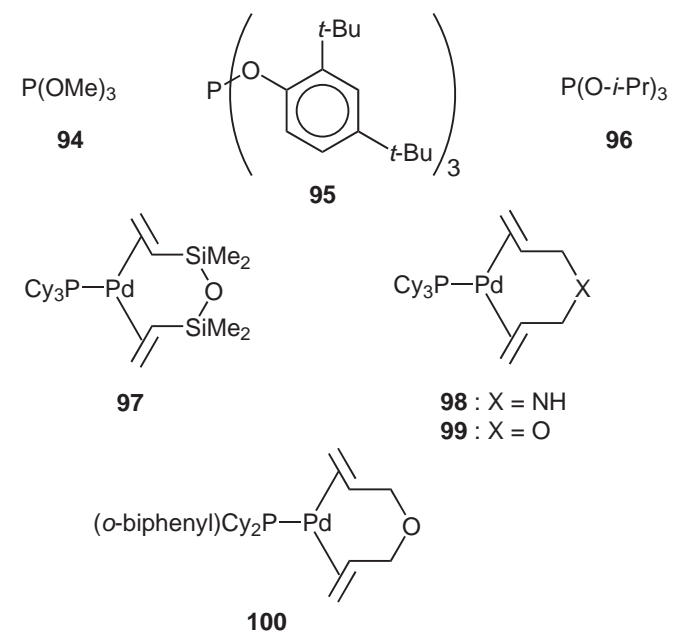

Figure 16

In $2001, \mathrm{Li}^{186}$ reported that the air-stable phosphine oxides 103 (Scheme 14) are another promising class of ligands for the palladium-catalysed Suzuki cross-couplings of unactivated aryl chlorides. These ligands and their less stable phosphinous acid tautomers 102 were generated by hydrolysis of the diorganophosphorus halides $\mathbf{1 0 1}$ (Scheme 14). In particular, it was found that binding a phosphinous acid $\mathbf{1 0 2}$ to palladium provides an adduct, 104, which may be deprotonated to give an anionic palla- dium-phosphine complex suitable as a catalyst for crosscouplings of aryl chlorides with arylboronic acids. ${ }^{186,187}$

An interesting alternative to existing catalytic systems based on the use of tertiary phosphine ligands was reported in 2001 by Nolan et al. ${ }^{188}$ who developed a catalyst system consisting of a combination of $\mathrm{Pd}(\mathrm{OAc})_{2}$ and $N, N^{\prime}$ dicyclohexyl-1,4-diazabutadiene (105) (Figure 17) for the reaction of aryl bromides and activated aryl chlorides with arylboronic acids. Investigation of other diazabutadiene ligands led to the observation that $N, N^{\prime}$-dialkyl-1,4-diazabutadienes are superior supporting ligands for the palladium-catalysed Suzuki reaction compared with $N, N^{\prime}$-diaryl1,4-diazabutadienes. ${ }^{188}$

Recently, Tao and Boykin ${ }^{189}$ have found that different substituents on the phenyl ring of 2-aryloxazolines have a dramatic influence on the Suzuki reaction of aryl bromides with arylboronic acids in dioxane at $80^{\circ} \mathrm{C}$ in the presence of $\mathrm{Cs}_{2} \mathrm{CO}_{3}$ as the base and the catalyst system consisting of a combination of $\mathrm{Pd}(\mathrm{OAc})_{2}$ and a 2-aryl-2oxazoline. Among the 2-aryl-2-oxazolines examined, compound 106 (Figure 17) was found to be the best ligand, providing the required biaryls in good to excellent yields.
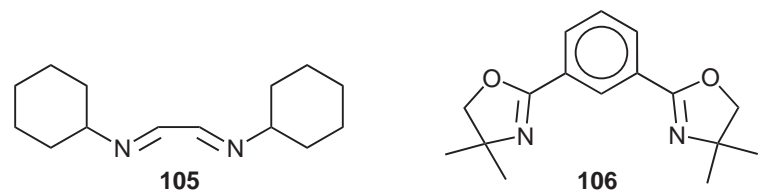

Figure 17

In 2001, Doucet, Santelli et al. investigated the synthesis ${ }^{190}$ and use ${ }^{191-195}$ of a new tetrapodal phosphine ligand, cis,cis,cis,cis-1,2,3,4-tetrakis(diphenylphosphinomethyl)cyclopentane (107) (Figure 18), and demonstrated that a combination of $\left[\mathrm{PdCl}\left(\eta^{3}-\mathrm{C}_{3} \mathrm{H}_{5}\right)\right]_{2}$ and this ligand produces an efficient catalyst for cross-couplings of aryl bromides, ${ }^{191-193}$ heteroaryl bromides ${ }^{191,194}$ and activated aryl chlorides ${ }^{195}$ with aryl boronic acids. Very high substrate-catalyst ratios (up to 5,000,000) could be used for the reactions between aryl bromides and arylboronic acids, and a turnover number of 28,000,000 was obtained for the reaction between 4-bromobenzophenone and phenylboronic acid in xylene at $130{ }^{\circ} \mathrm{C}$ in the presence of $\mathrm{K}_{2} \mathrm{CO}_{3}$ as the base. ${ }^{191}$

Recently, attention has also turned toward the application of sterically hindered phosphines based on a phospha-adamantane framework to palladium-catalysed Suzuki reactions. It has been demonstrated that the catalyst system consisting of a combination of $\mathrm{Pd}_{2}(\mathrm{dba})_{3}$ and 1,3,5,7-tetramethyl-2,4,8-trioxa-6-phenyl-6-phospha-adamantane (108) (Figure 18) is very active in promoting the coupling reactions of arylboronic acids with aryl halides, including an activated aryl chloride, at room temperature in high yields. ${ }^{196}$

Interestingly, the air-stable ligand $\mathbf{1 0 8}$ could be recovered by chromatography on silica gel and reused. 


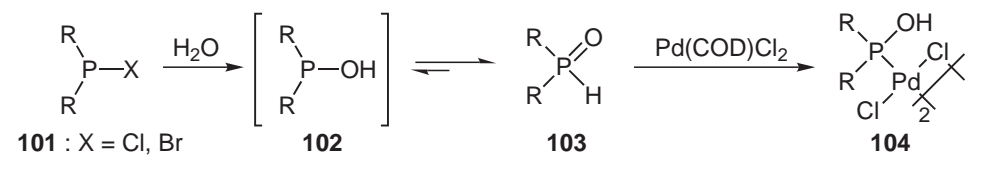

Scheme 14
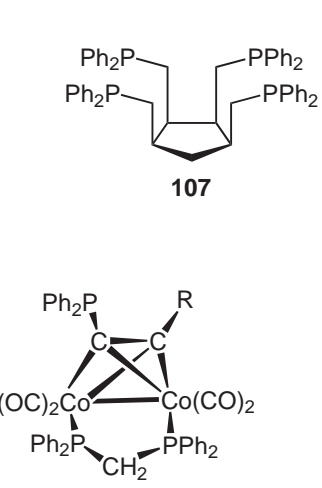

$110 \mathrm{a}: \mathrm{R}=\mathrm{Ph}$

$110 \mathrm{~b}: \mathrm{R}=t-\mathrm{Bu}$

110c $: R=\mathrm{SiMe}_{3}$

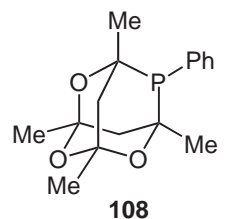

108

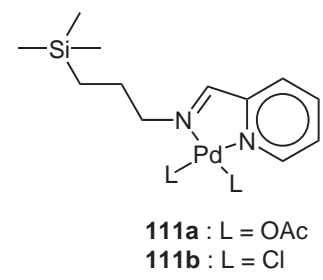<smiles></smiles>

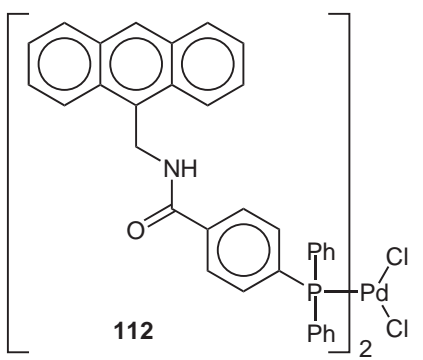

Figure 18

Nájera et al. ${ }^{197}$ recently reported that the dipyridylmethylamine-based Pd(II) complex 109 (Figure 18) is able to promote the reaction of aryl halides with phenylboronic acid and that the coupling involving aryl chlorides has to be run in the presence of TBAB as an additive.

In 2004, Hong et al. ${ }^{198}$ employed three cobalt-containing bulky phosphines, compounds 110a-c (Figure 18) as monodentate phosphine ligands in $\mathrm{Pd}(\mathrm{OAc})_{2}$-mediated reactions of (hetero)aryl bromides with phenylboronic acid. Mobufu, Clark and Macquarrie ${ }^{199}$ had previously described a range of silica-supported phosphine-free palladium-catalysed Suzuki reactions with notable features including fast and efficient reactions, catalyst stability under the reaction conditions, and very good catalyst recyclability. The most active precatalyst precursors were complexes 111a and 111b (Figure 18).

In 2003, Parlow et al. ${ }^{200}$ investigated the use of the anthracene-tagged palladium complex 112 (Figure 18) as precatalyst in polymer-assisted solution-phase Suzuki reaction of aryl bromides with anthracene-tagged boronic acids in the presence of a polymer-supported carbonate
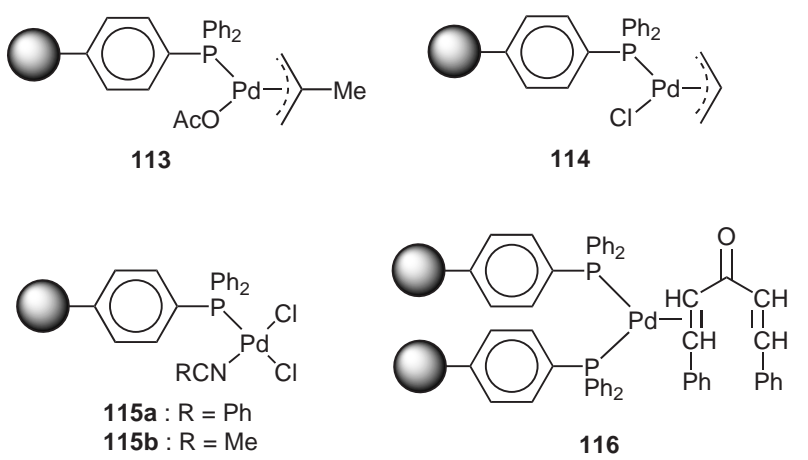

Figure 19 base. They also found that the use of this complex allows for easy removal of the palladium catalyst along with the dissociated phosphine ligand and phosphine oxide byproducts by sequestration through a Diels-Alder reaction with a maleimide resin. It is noteworthy that the coupling reactions performed by using the above mentioned conditions gave the required products in high purity and yield without the use of chromatography.

In 2002, high-throughput screening was used as a powerful tool in optimising the Suzuki reaction of activated and unactivated aryl bromides with phenylboronic acid. ${ }^{201} \mathrm{Re}-$ sults from this study indicate that the triphenylphosphinebased polymer-supported FibreCat precatalysts 113-116 (Figure 19) can be used to achieve room-temperature couplings in nearly quantitative conversions.

In 2003, an assembled precatalyst, PdAS, prepared from $\left(\mathrm{NH}_{4}\right)_{2} \mathrm{PdCl}_{4}$ and non-cross-linked amphiphilic polymer poly[( $\mathrm{N}$-isopropylacrylamide)-co-(4-diphenylstyrylphosphine)] was found to be an excellent catalyst precursor for heterogeneous Suzuki reactions. ${ }^{202}$ In fact, the coupling of aryl and alkenyl halides with aryl- and alkenylboronic acids was efficiently catalysed by $8 \times 10^{-7}$ to $5 \times 10^{-4}$ molar equivalents of PdAS with turnover numbers reaching up to $1,250,000$.

In the same year, $\mathrm{Hu}$ et al. ${ }^{203}$ designed and synthesised monophosphine-containing polymer 117 (Figure 20) which was then used for the room-temperature palladiumcatalysed reaction between aryl chlorides and arylboronic acids.

Very recently, in the course of an investigation on the asymmetric synthesis of compounds containing quaternary carbon atoms by a Suzuki reaction, Willis et al. ${ }^{204}$ found that the optimal catalyst for the enantioselective 
coupling of ditriflate $\mathbf{1 1 8}$ with arylboronic acids is generated from $\mathrm{Pd}(\mathrm{OAc})_{2}$ and phosphine 119 (Figure 20). The enantioselectivities obtained were up to $86 \%$ ee.

Also in 2004, Macquarrie et al. ${ }^{205}$ prepared the chitosanpyridine imine-based palladium complex 120 (Figure 20) and found that it is an excellent and reusable precatalyst for Suzuki reactions involving aryl and heteroaryl bromides.
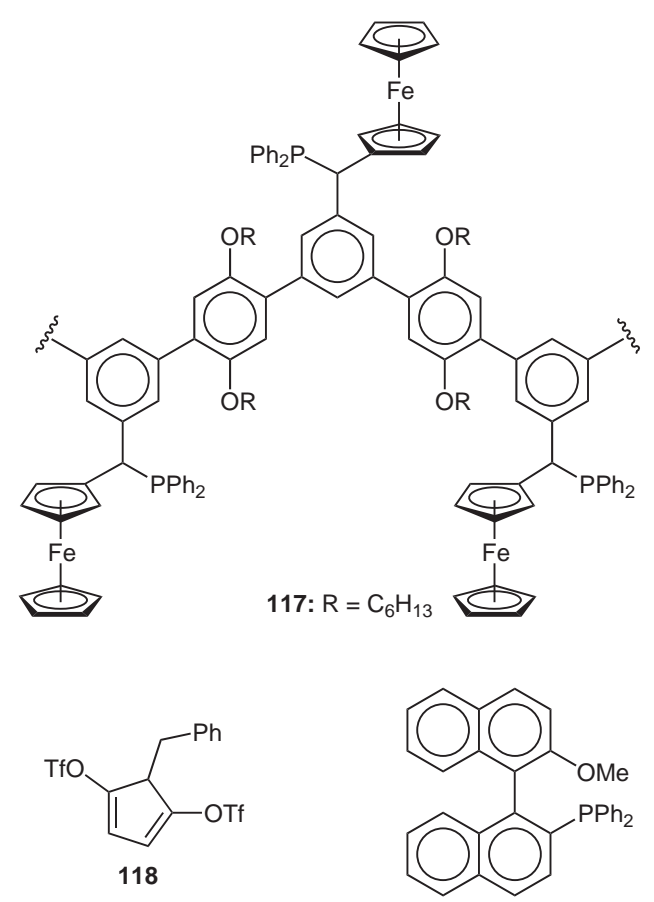

119

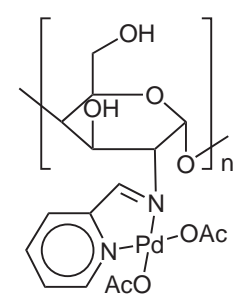

120

Figure 20

\section{Conclusions}

From this review, it is clear that recent advances in the design of palladium catalysts for the Suzuki reaction have resulted in several synthetically useful acquisitions. Thus, as reported in Section 2, palladacycle complexes have been found to be air- and thermally stable catalyst precursors that are suitable for recycling protocols and that can give very high turnover numbers and turnover frequencies. Moreover, some of them have been proven to be able to promote Suzuki reactions of activated and unactivated aryl chlorides, also under aerobic conditions. Thus, these complexes appear to be catalyst precursors superior to traditional palladium/triarylphosphine catalyst precursors, which are only effective for the coupling of certain activated (hetero)aryl chlorides.
As shown in Section 3 of this review, catalyst systems composed of a $\mathrm{Pd}(0)$ or a $\mathrm{Pd}(\mathrm{II})$ derivative and an electron-rich and/or bulky phosphine ligand have also been used for Suzuki reactions of both electron-rich and electron-deficient aryl chlorides. Moreover, these catalyst precursors have been successfully used for the room-temperature Suzuki coupling of aryl bromides and chlorides at low catalyst loading. ${ }^{68}$ This aspect is quite interesting since, before the use of these catalyst precursors, there were few examples in the literature of Suzuki couplings of aryl bromides that proceed at room temperature,,$^{19,140,141,206}$ and there were no reports of room-temperature Suzuki reactions involving aryl chlorides. Other capabilities of these catalyst precursors include the following: synthesis of hindered di- and tri-ortho-substituted biaryls ${ }^{53}$ cross-coupling of 9-alkyl-9-borabicyclo[3.3.1]nonanes with alkyl chlorides $;{ }^{54}$ and cross-coupling of uncomplexed electron-poor aryl fluorides with arylboronic acids. ${ }^{94 a}$

In Section 4 of this review, it was shown that catalyst systems composed of $\mathrm{Pd}(0)$ or $\mathrm{Pd}(\mathrm{II})$ derivatives and $N$-heterocyclic carbene ligands can be active for Suzuki reactions which can be alternatively performed, sometimes under similar reaction conditions, using palladacycle complexes as catalyst precursors or catalyst systems composed of a $\mathrm{Pd}(0)$ or a $\mathrm{Pd}(\mathrm{II})$ derivative and an electron-rich and/or bulky phosphine ligand. However, the scope of the $\mathrm{Pd} /$ carbene-catalysed Suzuki reactions of aryl chlorides has been significantly expanded by employing 9-alkyl-, 9-allyl-, 9-(1-alkenyl)- and 9-cyclopropyl-9-borabicyclo[3.3.1]nonane derivatives as coupling partners. ${ }^{107}$

It should also be mentioned that a drawback of the protocols involving the use of $N$-heterocyclic carbenes is that these compounds are air- and moisture-sensitive. However, their handling can be avoided through the use of the corresponding, easier to handle, commercially available chloride salts, which can be deprotonated in situ to generate the required carbene ligands.

Section 5 of this review was devoted to the description of water-soluble catalyst systems for the Suzuki reaction that can be easily separated from the organic-soluble products at the end of the transformation. The use of these catalyst systems, which operate in a two-phase system, could offer advantages for the industrial production of fine chemicals in comparison to protocols involving homogeneous catalysis.

Section 6 was devoted to a discussion of the use of ligandless palladium catalyst precursors. The use of these precatalysts can overcome the problems pertaining to the Suzuki cross-coupling reactions where expensive palladium complexes, which are difficult to prepare and recover, are used as catalyst precursors. Nevertheless, it should be mentioned that although the ligandless palladium precatalysts often achieve significantly fast cross-couplings in aqueous media, complete conversion is not always possi- 
ble, particularly for slow reactions of electron-rich and sterically hindered haloarenes. ${ }^{11}$

Finally, the capabilities of several other novel palladium catalyst precursors were described in Section 7. Some of these Pd systems, such as PdAS and complex 112, have been found to be excellent catalyst precursors for heterogeneous Suzuki reactions and other Pd systems, such as that composed of a combination of $\left[\mathrm{PdCl}\left(\eta^{3}-\mathrm{C}_{3} \mathrm{H}_{5}\right)\right]_{2}$ and ligand 107, or those composed of the 1,6-diene palladium( 0 ) monophosphine complexes $\mathbf{9 7 - 1 0 0}$, have proven to be extremely efficient catalyst precursors for Suzuki cross-coupling reactions of aryl chlorides, and appear to be superior to generally applied mixtures of Pd(II)-derivatives and phosphine ligands. These findings are rather important since there are relatively few examples of Suzuki cross-couplings of aryl chlorides that proceed at low catalyst loadings ( $0.05 \mathrm{~mol} \% \mathrm{Pd}) .{ }^{66,70,185,192}$

Nevertheless, despite these important results, a number of challenges, especially with regard to industrial applications of the Suzuki coupling reactions, remain. In fact, even though some successful results in the preparation and use of efficient heterogeneous catalyst systems have been obtained, it is still necessary to develop much more effective and low-cost heterogeneous catalysts which are able to work in very mild conditions. These ideal catalysts will be characterised by high stability under the reaction conditions, very good recyclability and very high turnover numbers and turnover frequencies and, thus, will provide a significant practical benefit to industry.

\section{References}

(1) Smith, G. B.; Dezeny, G. C.; Hughes, D. L.; King, A. O.; Verhoeven, T. R. J. Org. Chem. 1994, 59, 8151.

(2) Ennis, D. S.; McManus, J.; Wood-Kaczmar, W.; Richardson, J.; Smith, G. E.; Carstairs, A. Org. Process Res. Dev. 1999, 3, 248.

(3) Jacks, T. E.; Belmont, D. T.; Briggs, C. A.; Horne, N. M.; Kanter, G. D.; Karrick, G. L.; Krikke, J. J.; McCabe, R. J.; Mustakis, J. G.; Nanninga, T. N.; Risedorph, G. S.; Seamans, R. E.; Skeenan, R. E.; Winkle, D. D.; Zennie, T. M. Org. Process Res. Dev. 2004, 8, 201.

(4) Miyaura, N.; Suzuki, A. Chem. Rev. 1995, 95, 2457.

(5) Suzuki, A. In Metal-Catalyzed Cross-Coupling Reactions; Diederich, F.; Stang, P. J., Eds.; Wiley-VCH: Weinheim, 1998, 49-97.

(6) Suzuki, A. Pure Appl. Chem. 1994, 66, 213.

(7) Stanforth, S. P. Tetrahedron 1998, 54, 263.

(8) Suzuki, A. J. Organomet. Chem. 1999, 576, 147.

(9) Suzuki, A. In Organoboranes for Syntheses. ACS Symposium Series 783; Ramachandran, P. V.; Brown, H. C., Eds.; American Chemical Society: Washington DC, 2001, 80-93.

(10) Kotha, S.; Lahiri, K.; Kashinath, D. Tetrahedron 2002, 58, 9633.

(11) Miyaura, N. Top. Curr. Chem. 2002, 219, 11

(12) Lloyd-Williams, P.; Giralt, E. Chem. Soc. Rev. 2001, 30, 145.

(13) Littke, A. F.; Fu, G. C. Angew. Chem. Int. Ed. 2002, 41, 4176.
(14) Herrmann, W. A.; Böhm, V. P. W.; Reisinger, C.-P. J. Organomet. Chem. 1999, 576, 23.

(15) Dupont, J.; Pfeffer, M.; Spencer, J. Eur. J. Inorg. Chem. 2001, 1917.

(16) Shaw, B. L. New J. Chem. 1998, 77.

(17) Beller, M.; Fischer, H.; Herrmann, W. A.; Öfele, K.; Brossmer, C. Angew. Chem., Int. Ed. Engl. 1995, 34, 1848.

(18) Darses, S.; Michaud, G.; Genêt, J.-P. Eur. J. Org. Chem. 1999, 1875.

(19) Albisson, D. A.; Bedford, R. B.; Lawrence, S. E.; Scully, P. N. Chem. Commun. 1998, 2095.

(20) Bedford, R. B.; Hazelwood (née Welch), S. L.; Limmert, M. E.; Albisson, D. A.; Draper, S. M.; Scully, P. N.; Coles, S. J.; Hursthouse, M. B. Chem.-Eur. J. 2003, 9, 3216.

(21) Weissman, H.; Milstein, D. Chem. Commun. 1999, 1901.

(22) Alonso, D. A.; Nájera, C.; Pacheco, M. C. Org. Lett. 2000, 2, 1823.

(23) Alonso, D. A.; Nájera, C.; Pacheco, M. C. J. Org. Chem. 2002, 67, 5588 .

(24) Botella, L.; Nájera, C. Angew. Chem. Int. Ed. 2002, 41, 179.

(25) Botella, L.; Nájera, C. J. Organomet. Chem. 2002, 663, 46.

(26) Alonso, D. A.; Botella, L.; Nájera, C.; Pacheco, M. C. Synthesis 2004, 1713.

(27) Bedford, R. B.; Draper, S. M.; Scully, P. N.; Welch, S. L. New J. Chem. 2000, 24, 745.

(28) Bedford, R. B.; Welch, S. Chem. Commun. 2001, 129.

(29) Zim, D.; Gruber, A. S.; Ebeling, G.; Dupont, J.; Monteiro, A. L. Org. Lett. 2000, 2, 2881.

(30) Albisson, D. A.; Bedford, R. B.; Scully, P. N. Tetrahedron Lett. 1998, 39, 9793.

(31) Bedford, R. B.; Cazin, C. S. J. Chem. Commun. 2001, 1540.

(32) Bedford, R. B.; Cazin, C. S. J.; Coles, S. J.; Gelbrich, T.; Hursthouse, M. B.; Scordia, V. J. M. J. Chem. Soc., Dalton Trans. 2003, 3350.

(33) Bedford, R. B.; Cazin, C. S. J.; Coles, S. J.; Gelbrich, T.; Horton, P. N.; Hursthouse, M. B.; Light, M. E. Organometallics 2003, 22, 987.

(34) Bedford, R. B.; Cazin, C. S. J.; Hursthouse, M. B.; Light, M. E.; Pike, K. J.; Wimperis, S. J. Organomet. Chem. 2001, $633,173$.

(35) Gibson, S.; Foster, D. F.; Eastham, G. R.; Tooze, R. P.; ColeHamilton, D. J. Chem. Commun. 2001, 779.

(36) Schnyder, A.; Indolese, A. F.; Studer, M.; Blaser, H.-U. Angew. Chem. Int. Ed. 2002, 41, 3668.

(37) Bellina, F.; Anselmi, C.; Martina, F.; Rossi, R. Eur. J. Org. Chem. 2003, 68, 2290.

(38) Bedford, R. B.; Cazin, C. S. J.; Hazelwood (née Welch), S. L. Angew. Chem. Int. Ed. 2002, 41, 4120.

(39) Bedford, R. B.; Hazelwood (née Welch), S. L.; Limmert, M. E. Chem. Commun. 2002, 2610.

(40) Roca, F. X.; Richards, C. J. Chem. Commun. 2003, 3002.

(41) Thakur, V. V.; Kumar, N. S. C. R.; Sudalai, A. Tetrahedron Lett. 2004, 45, 2915.

(42) Bedford, R. B. Chem. Commun. 2003, 1787.

(43) Li, J. J.; Gribble, G. W. Palladium in Heterocyclic Chemistry: A guide for the synthetic chemist; Elsevier: Oxford, 2000.

(44) (a) Uemura, M.; Nishimura, H.; Kamikawa, K.; Nakayama, K.; Hayashi, Y. Tetrahedron Lett. 1994, 35, 1909. (b) Uemura, M.; Nishimura, H.; Hayashi, T. J. Organomet. Chem. 1994, 473, 129. (c) See ref. 17. (d) Mitchell, M. B.; Wallbank, P. J. Tetrahedron Lett. 1991, 32, 2273.

(45) Shen, W. Tetrahedron Lett. 1997, 38, 5575.

(46) Firooznia, F.; Gude, C.; Chan, K.; Satoh, Y. Tetrahedron Lett. 1998, 39, 3985.

(47) McKenna, J. M.; Moliterni, J.; Qiao, Y. Tetrahedron Lett. 2001, 42, 5797. 
(48) Minutolo, F.; Bertini, S.; Papi, C.; Carlson, K. E.; Katzenellenbogen, J. A.; Macchia, M. J. Med. Chem. 2001, 44, 4288.

(49) McClure, M. S.; Glover, B.; McSorley, E.; Millar, A.; Osterhout, M. H.; Roschangar, F. Org. Lett. 2001, 3, 1677.

(50) Monteith, M. J. WO 9816486, 1998.

(51) Monteith, M. J. Spec. Chem. 1998, 18, 436.

(52) Littke, A. F.; Fu, G. C. Angew. Chem. Int. Ed. 1998, 37, 3387.

(53) Littke, A. F.; Dai, C.; Fu, G. C. J. Am. Chem. Soc. 2000, 122, 4020.

(54) Kirchhoff, J. H.; Dai, C.; Fu, G. C. Angew. Chem. Int. Ed. 2002, 41, 1945.

(55) Allegretti, M.; Arcadi, A.; Marinelli, F.; Nicolini, L. Synlett 2001, 609.

(56) Brill, W. K.-D.; Riva-Toniolo, C.; Müller, S. Synlett 2001, 1097.

(57) Sutton, A. E.; Clardy, J. Tetrahedron Lett. 2001, 42, 547.

(58) Mello, J. V.; Finney, N. S. Org. Lett. 2001, 3, 4263.

(59) Zou, G.; Falck, J. R. Tetrahedron Lett. 2001, 42, 5817.

(60) Bellina, F.; Rossi, R. unpublished results.

(61) Bellina, F.; Anselmi, C.; Rossi, R. Tetrahedron Lett. 2002, 43, 2023.

(62) Rossi, R.; Bellina, F. unpublished results.

(63) Netherton, M. R.; Fu, G. C. Org. Lett. 2001, 3, 4295

(64) Zhong, Y.-L.; Lee, J.; Reamer, R. A.; Askin, D. Org. Lett. 2004, 6, 929.

(65) Kirchhoff, J. H.; Netherton, M. R.; Hills, I. D.; Fu, G. C. J. Am. Chem. Soc. 2002, 124, 13662.

(66) Zapf, A.; Ehrentraut, A.; Beller, M. Angew. Chem. Int. Ed. 2000, 39, 4153.

(67) Stambuli, J. P.; Kuwano, R.; Hartwig, J. F. Angew. Chem. Int. Ed. 2002, 41, 4746.

(68) Old, D. W.; Wolfe, J. P.; Buchwald, S. L. J. Am. Chem. Soc. 1998, 120, 9722.

(69) Wolfe, J. P.; Buchwald, S. L. Angew. Chem. Int. Ed. 1999, $38,2413$.

(70) Wolfe, J. P.; Singer, R. A.; Yang, B. H.; Buchwald, S. L. J. Am. Chem. Soc. 1999, 121, 9550.

(71) Yin, J.; Buchwald, S. L. J. Am. Chem. Soc. 2000, 122, 12051

(72) Yin, J.; Rainka, M. P.; Zhang, X.-X.; Buchwald, S. L. J. Am. Chem. Soc. 2002, 124, 1162.

(73) Nguyen, H. N.; Huang, X.; Buchwald, S. L. J. Am. Chem. Soc. 2003, 125, 11818.

(74) Walker, S. D.; Barder, T. E.; Martinelli, J. R.; Buchwald, S. L. Angew. Chem. Int. Ed. 2004, 43, 1871.

(75) Dyer, U. C.; Shapland, P. D.; Tiffin, P. D. Tetrahedron Lett. 2001, 42, 1765.

(76) Tagata, T.; Nishida, M. J. Org. Chem. 2003, 68, 9412.

(77) Lakshman, M. K.; Hilmer, J. H.; Martin, J. Q.; Keeler, J. C.; Dinh, Y. Q. V.; Ngassa, F. N.; Russon, L. M. J. Am. Chem. Soc. 2001, 123, 7779.

(78) Lakshman, M. K.; Thompson, P. F.; Nuqui, M. A.; Hilmer, J. H.; Sevova, N.; Boggess, B. Org. Lett. 2002, 4, 1479.

(79) Sugihara, S.; Kuroda, N.; Wada, M.; Nakashima, K. Anal. Sci. 2001, 17 (Supplement I), 1261.

(80) Kotharé, M. A.; Ohkanda, J.; Lockman, J. W.; Qian, Y.; Blaskovich, M. A.; Sebti, S. M.; Hamilton, A. D. Tetrahedron 2000, 56, 9833.

(81) Parrish, C. A.; Buchwald, S. L. J. Org. Chem. 2001, 66, 3820.

(82) Zapf, A.; Jackstell, R.; Rataboul, F.; Riermeier, T.; Monsees, A.; Fuhrmann, C.; Shaikh, N.; Dingerdissen, U.; Beller, M. Chem. Commun. 2004, 38.

(83) Pickett, T. E.; Richards, C. J. Tetrahedron Lett. 2001, 42, 3767.
(84) Pickett, T. E.; Roca, F. X.; Richards, C. J. J. Org. Chem. 2003, 68, 2592.

(85) Liu, S.-Y.; Choi, M. J.; Fu, G. C. Chem. Commun. 2001, 2408.

(86) Kataoka, N.; Shelby, Q.; Stambuli, J. P.; Hartwig, J. F. J. Org. Chem. 2002, 67, 5553.

(87) Jensen, J. F.; Johannsen, M. Org. Lett. 2003, 5, 3025.

(88) Cammidge, A. N.; Crépy, K. V. L. Chem. Commun. 2000, 1723.

(89) Bei, X.; Crevier, T.; Guram, A. S.; Jandeleit, B.; Powers, T. S.; Turner, H. W.; Uno, T.; Weinberg, W. H. Tetrahedron Lett. 1999, 40, 3855.

(90) Bei, X.; Turner, H. W.; Weinberg, W. H.; Guram, A. S.; Petersen, J. L. J. Org. Chem. 1999, 64, 6797.

(91) Clarke, M. L.; Cole-Hamilton, D. J.; Woollins, J. D. J. Chem. Soc., Dalton Trans. 2001, 2721.

(92) Cheng, J.; Wang, F.; Xu, J.-H.; Pan, Y.; Zhang, Z. Tetrahedron Lett. 2003, 44, 7095.

(93) Urgaonkar, S.; Nagarajan, M.; Verkade, J. G. Tetrahedron Lett. 2002, 43, 8921.

(94) (a) Widdowson, D. A.; Wilhelm, R. Chem. Commun. 2003, 578. (b) Wilhelm, R.; Widdowson, D. A. J. Chem. Soc., Perkin Trans. 1 2000, 3808. (c) Widdowson, D. A.; Wilhelm, R. Chem. Commun. 1999, 2211.

(95) (a) Hegedus, L. S. In Organometallics in Synthesis: A Manual, 2nd ed.; Schlosser, M., Ed.; Wiley: New York, 2002, 1123-1217. (b) Grushin, V. V. Chem.-Eur. J. 2002, 8, 1006.

(96) Kim, Y. M.; Yu, S. J. Am. Chem. Soc. 2003, 125, 1696.

(97) Retboll, M.; Edwards, A. J.; Rae, A. D.; Willis, A. C.; Bennett, M. A.; Wenger, E. J. Am. Chem. Soc. 2002, 124, 8348.

(98) Regitz, M. Angew. Chem., Int. Ed. Engl. 1996, 35, 725.

(99) Herrmann, W. A. Angew. Chem. Int. Ed. 2002, 41, 1290.

(100) Hillier, A. C.; Grasa, G. A.; Viciu, M. S.; Lee, H. M.; Yang, C.; Nolan, S. P. J. Organomet. Chem. 2002, 653, 69.

(101) Weskamp, T.; Kohl, F. J.; Hieringer, W.; Gleich, D.; Herrmann, W. A. Angew. Chem. Int. Ed. 1999, 38, 241.

(102) Grasa, G. A.; Viciu, M. S.; Huang, J.; Zhang, C.; Trudell, M. L.; Nolan, S. P. Organometallics 2002, 21, 2866.

(103) Herrmann, W. A.; Reisinger, C.-P.; Spiegler, M. J. Organomet. Chem. 1998, 557, 93.

(104) Zhang, C.; Huang, J.; Trudell, M. L.; Nolan, S. P. J. Org. Chem. 1999, 64, 3804.

(105) Ding, S.; Gray, N. S.; Ding, Q.; Schultz, P. G. Tetrahedron Lett. 2001, 42, 8751.

(106) Zhang, C.; Trudell, M. L. Tetrahedron Lett. 2000, 41, 595.

(107) Fürstner, A.; Leitner, A. Synlett 2001, 290.

(108) Böhm, V. P. W.; Gstöttmayr, C. W. K.; Weskamp, T.; Herrmann, W. A. J. Organomet. Chem. 2000, 595, 186.

(109) Gstöttmayr, C. W. K.; Böhm, V. P. W.; Herdtweck, E.; Grosche, M.; Herrmann, W. A. Angew. Chem. Int. Ed. 2002, $41,1364$.

(110) Weskamp, T.; Böhm, V. P. W.; Herrmann, W. A. J. Organomet. Chem. 1999, 585, 348.

(111) Herrmann, W. A.; Böhm, V. P. W.; Gstöttmayr, C. W. K.; Grosche, M.; Reisinger, C.-P.; Weskamp, T. J. Organomet. Chem. 2001, 617-618, 616.

(112) Altenhoff, G.; Goddard, R.; Lehmann, C. W.; Glorius, F. Angew. Chem. Int. Ed. 2003, 42, 3690.

(113) Schwarz, J.; Böhm, V. P. W.; Gardiner, M. G.; Grosche, M.; Herrmann, W. A.; Hieringer, W.; Raudaschl-Sieber, G. Chem.-Eur. J. 2000, 6, 1773.

(114) Lin, K.; Song, M.; Cai, M.; Hao, X.; Wu, Y. Tetrahedron Lett. 2003, 44, 3955.

(115) Byun, J.-W.; Lee, Y.-S. Tetrahedron Lett. 2004, 45, 1837. 
(116) Mathews, C. J.; Smith, P. J.; Welton, T. Chem. Commun. 2000, 1249.

(117) Mathews, C. J.; Smith, P. J.; Welton, T.; White, A. J. P.; Williams, D. J. Organometallics 2001, 20, 3848.

(118) McLachlan, F.; Mathews, C. J.; Smith, P. J.; Welton, T. Organometallics 2003, 22, 5350.

(119) Casalnuovo, A. L.; Calabrese, J. C. J. Am. Chem. Soc. 1990, 112, 4324.

(120) Wallow, T. I.; Novak, B. M. J. Am. Chem. Soc. 1991, 113, 7411.

(121) Genêt, J. P.; Linquist, A.; Blart, E.; Mouriès, V.; Savignac, M.; Vaultier, M. Tetrahedron Lett. 1995, 36, 1443

(122) Genêt, J. P.; Blart, E.; Savignac, M. Synlett 1992, 715.

(123) Dupuis, C.; Adiey, K.; Charruault, L.; Michelet, V.; Savignac, M.; Genêt, J. P. Tetrahedron Lett. 2001, 42, 6523.

(124) Paetzold, E.; Oehme, G. J. Mol. Catal. A: Chem. 2000, 152, 69.

(125) Beller, M.; Krauter, J. G. E.; Zapf, A. Angew. Chem., Int. Ed. Engl. 1997, 36, 772.

(126) Ueda, M.; Nishimura, M.; Miyaura, N. Synlett 2000, 856.

(127) Uozumi, Y.; Danjo, H.; Hayashi, T. J. Org. Chem. 1999, 64, 3384.

(128) Shaughnessy, K. H.; Booth, R. S. Org. Lett. 2001, 3, 2757.

(129) Moore, L. R.; Shaughnessy, K. H. Org. Lett. 2004, 6, 225.

(130) Wallow, T. I.; Novak, B. M. J. Org. Chem. 1994, 59, 5034.

(131) Kong, K.-C.; Cheng, C.-H. J. Am. Chem. Soc. 1991, 113, 6313.

(132) Herrmann, W. A.; Brossmer, C.; Priermeier, T.; Öfele, K. J. Organomet. Chem. 1994, 481, 97.

(133) Migita, T.; Nagai, T.; Kiuchi, K.; Kosugi, M. Bull. Chem. Soc. Jpn. 1983, 56, 2869.

(134) Beletskaya, I. P. J. Organomet. Chem. 1983, 250, 551.

(135) Marck, G.; Villiger, A.; Buchecker, R. Tetrahedron Lett. 1994, 35, 3277.

(136) Moreno-Mañas, M.; Pajuelo, F.; Pleixats, R. J. Org. Chem. 1995, 60, 2396.

(137) O'Keefe, D. F.; Dannock, M. C.; Marcuccio, S. M. Tetrahedron Lett. 1992, 33, 6679.

(138) Goodson, F. E.; Wallow, T. I.; Novak, B. M. Org. Synth. 1998, 75, 61 .

(139) Badone, D.; Baroni, M.; Cardamone, R.; Ielmini, A.; Guzzi, U. J. Org. Chem. 1997, 62, 7170.

(140) Bussolari, J. C.; Rehborn, D. C. Org. Lett. 1999, 1, 965.

(141) Bumagin, N. A.; Bykov, V. V. Tetrahedron 1997, 53, 14437.

(142) Campi, E. M.; Jackson, W. R.; Marcuccio, S. M.; Naeslund, C. G. M. J. Chem. Soc., Chem. Commun. 1994, 2395.

(143) Taylor, P. N.; O'Connell, M. J.; McNeill, L. A.; Hall, M. J.; Aplin, R. T.; Anderson, H. L. Angew. Chem. Int. Ed. 2000, $39,3456$.

(144) Turrin, C.-O.; Chiffre, J.; Daran, J.-C.; de Montauzon, D.; Caminade, A.-M.; Manoury, E.; Balavoine, G.; Majoral, J.P. Tetrahedron 2001, 57, 2521.

(145) Mamane, V.; Riant, O. Tetrahedron 2001, 57, 2555.

(146) Molander, G. A.; Biolatto, B. Org. Lett. 2002, 4, 1867.

(147) Darses, S.; Jeffery, T.; Genêt, J.-P.; Brayer, J.-L.; Demoute, J.-P. Tetrahedron Lett. 1996, 37, 3857.

(148) Sengupta, S.; Bhattacharyya, S. J. Org. Chem. 1997, 62, 3405 .

(149) Christoforou, I. C.; Koutentis, P. A.; Rees, C. W. Org. Biomol. Chem. 2003, 1, 2900.

(150) Bedford, R. B.; Blake, M. E.; Butts, C. P.; Holder, D. Chem. Commun. 2003, 466.

(151) Hesse, S.; Kirsch, G. Synthesis 2001, 755.

(152) Moreno-Mañas, M.; Pérez, M.; Pleixats, R. J. Org. Chem. 1996, 61, 2346.

(153) Smith, K. A.; Campi, E. M.; Jackson, W. R.; Marcuccio, S.; Naeslund, C. G. M.; Deacon, G. B. Synlett 1997, 131.
(154) Deng, Y.; Gong, L.; Mi, A.; Liu, H.; Jang, Y. Synthesis 2003, 337.

(155) Tao, X.; Zhao, Y.; Shen, D. Synlett 2004, 359.

(156) Bumagin, N. A.; Korolev, D. N. Tetrahedron Lett. 1999, 40, 3057.

(157) Walsh, C. J.; Mandal, B. K. Chem. Mater. 2001, 13, 2472.

(158) McClure, M. S.; Roschangar, F.; Hodson, S. J.; Millar, A.; Osterhout, M. H. Synthesis 2001, 1681.

(159) Leadbeater, N. E.; Marco, M. Org. Lett. 2002, 4, 2973.

(160) Leadbeater, N. E.; Marco, M. Angew. Chem. Int. Ed. 2003, 42, 1407.

(161) Blettner, C. G.; König, W. A.; Stenzel, W.; Schotten, T. J. Org. Chem. 1999, 64, 3885.

(162) Blettner, C. G.; König, W. A.; Rühter, G.; Stenzel, W.; Schotten, T. Synlett 1999, 307.

(163) Villemin, D.; Gómez-Escalonilla, M. J.; Saint-Clair, J.-F. Tetrahedron Lett. 2001, 42, 635.

(164) Zim, D.; Monteiro, A. L.; Dupont, J. Tetrahedron Lett. 2000, $41,8199$.

(165) Kabalka, G. W.; Namboodiri, V.; Wang, L. Chem. Commun. 2001, 775.

(166) Kabalka, G. W.; Pagni, R. M.; Hair, C. M. Org. Lett. 1999, $1,1423$.

(167) Kabalka, G. W.; Wang, L.; Pagni, R. M.; Hair, C. M.; Namboodiri, V. Synthesis 2003, 217.

(168) Villemin, D.; Caillot, F. Tetrahedron Lett. 2001, 42, 639.

(169) Gala, D.; Stamford, A.; Jenkins, J.; Kugelman, M. Org. Process Res. Dev. 1997, 1, 163.

(170) LeBlond, C. R.; Andrews, A. T.; Sun, Y.; Sowa, J. R. Jr. Org. Lett. 2001, 3, 1555.

(171) Heidenreich, R. G.; Köhler, K.; Krauter, J. G. E.; Pietsch, J. Synlett 2002, 1118.

(172) Li, Y.; Hong, X. M.; Collard, D. M.; El-Sayed, M. A. Org. Lett. 2000, 2, 2385.

(173) Kim, S.-W.; Kim, M.; Lee, W. Y.; Hyeon, T. J. Am. Chem. Soc. 2002, 124, 7642.

(174) Liu, Y.; Khemtong, C.; Hu, J. Chem. Commun. 2004, 398.

(175) Reetz, M. T.; Westermann, E. Angew. Chem. Int. Ed. 2000, $39,165$.

(176) McNulty, J.; Capretta, A.; Wilson, J.; Dyck, J.; Adjabeng, G.; Robertson, A. Chem. Commun. 2002, 1986.

(177) Rajagopal, R.; Jarikote, D. V.; Srinivasan, K. V. Chem. Commun. 2002, 616.

(178) Varma, R. S.; Naicker, K. P. Tetrahedron Lett. 1999, 40, 439.

(179) Paul, S.; Clark, J. H. Green Chem. 2003, 5, 635.

(180) Yao, M.-L.; Deng, M.-Z. J. Org. Chem. 2000, 65, 5034.

(181) Bellina, F.; Anselmi, C.; Rossi, R. Tetrahedron Lett. 2001, 42, 3851

(182) Bellina, F.; Anselmi, C.; Viel, S.; Mannina, L.; Rossi, R. Tetrahedron 2001, 57, 9997.

(183) Griffiths, C.; Leadbeater, N. E. Tetrahedron Lett. 2000, 41, 2487.

(184) Zapf, A.; Beller, M. Chem.-Eur. J. 2000, 6, 1830.

(185) Andreu, M. G.; Zapf, A.; Beller, M. Chem. Commun. 2000, 2475.

(186) Li, G. Y. Angew. Chem. Int. Ed. 2001, 40, 1513.

(187) Li, G. Y. J. Org. Chem. 2002, 67, 3643.

(188) Grasa, G. A.; Hillier, A. C.; Nolan, S. P. Org. Lett. 2001, 3, 1077.

(189) Tao, B.; Boykin, D. W. Tetrahedron Lett. 2002, 43, 4955.

(190) Feuerstein, M.; Laurenti, D.; Doucet, H.; Santelli, M. Chem. Commun. 2001, 43.

(191) Feuerstein, M.; Laurenti, D.; Bougeant, C.; Doucet, H.; Santelli, M. Chem. Commun. 2001, 325.

(192) Feuerstein, M.; Doucet, H.; Santelli, M. Tetrahedron Lett. 2001, 42, 6667. 
(193) Feuerstein, M.; Laurenti, D.; Doucet, H.; Santelli, M. Synthesis 2001, 2320.

(194) Feuerstein, M.; Doucet, H.; Santelli, M. Tetrahedron Lett. 2001, 42, 5659 .

(195) Feuerstein, M.; Doucet, H.; Santelli, M. Synlett 2001, 1458.

(196) Adjabeng, G.; Brenstrum, T.; Wilson, J.; Framton, C.;

Robertson, A.; Hillhouse, J.; McNulty, J.; Capretta, A. Org. Lett. 2003, 5, 953.

(197) Nájera, C.; G il-Moltó, J.; Karlström, S.; Falvella, L. R. Org. Lett. 2003, 5, 1451.

(198) Hong, F.-E.; Ho, Y.-J.; Chang, Y.-C.; Lai, Y.-C. Tetrahedron 2004, 60, 2639.

(199) Mobufu, E. B.; Clark, J. H.; Macquarrie, D. J. Green Chem. 2001, 3, 23.
(200) Lan, P.; Berta, D.; Porco, J. A. JR.; South, M. S.; Parlow, J. J. J. Org. Chem. 2003, 68, 9678.

(201) Colacot, T. J.; Gore, E. S.; Kuber, A. Organometallics 2002, $21,3301$.

(202) Yamada, Y. M. A.; Takeda, K.; Takahashi, H.; Ikegami, S. J. Org. Chem. 2003, 68, 7733.

(203) Hu, Q.-S.; Lu, Y.; Tang, Z.-Y.; Yu, H.-B. J. Am. Chem. Soc. 2003, 125, 2856.

(204) Willis, M. C.; Powell, L. H. W.; Claverie, C. K.; Watson, S. J. Angew. Chem. Int. Ed. 2004, 43, 1249.

(205) Hardy, J. J. E.; Hubert, S.; Macquarrie, D. J.; Wilson, A. J. Green Chem. 2004, 6, 53.

(206) (a) See ref. 127. (b) Kamatani, A.; Overman, L. E. J. Org. Chem. 1999, 64, 8743. (c) Anderson, J. C.; Namli, H.; Roberts, C. A. Tetrahedron 1997, 44, 15123. 